\title{
Does the Strength of Incentives Matter for Elected Officials? A Look at
}

\author{
Tax Collectors*
}

Sutirtha Bagchi ${ }^{\dagger}$

March 16, 2017

\begin{abstract}
In Pennsylvania local property taxes are collected by elected officials, known as tax collectors, whose compensation varies widely in both structure and level across municipalities. This paper analyses the existence of a pay-performance relationship for these officials. Using data on the percentage of real estate taxes that are actually collected at the municipal level, the paper finds that as the compensation tax collectors receive goes up, they collect more in taxes. This relationship is however true only for collectors who are compensated on a commission basis and not for collectors compensated on the basis of a flat salary. The paper also finds no relationship between the share of votes received by the tax collector and the percentage of property taxes collected during the previous term. This observation may account for the lack of a positive relationship between pay and performance for collectors compensated on the basis of a salary.

Keywords: Tax Collectors; Politician Salary; Productivity; Pay for Performance

JEL codes: H70 (State and Local Government), J45 (Public Sector Labor Markets), J33 (Wage Level and Structure), D72 (Political Processes: Rent-Seeking, Lobbying, Elections, Legislatures, and Voting Behavior), and M52 (Compensation and Compensation Methods and Their Effects)
\end{abstract}

${ }^{*}$ I thank Gerald Cross of the Pennsylvania Economy League for sharing survey data on compensation of tax collectors and Sharon Bogden of the Department of General Services of Pennsylvania and Rhonda R. Newton of the Pennsylvania Heritage Foundation for help in obtaining issues of the Pennsylvania Manual. I also thank (without implicating) Sebastien Bradley, Adam Cole, and Björn Kauder along with seminar participants at the University of Michigan, the American Economic Association Annual Meeting 2017, the International Institute of Public Finance Annual Congress 2016, the National Tax Association Conference 2015, and the Society of Labor Economists Annual Meeting 2016 for comments on an earlier version of the paper. All links were current as of 03/10/2017. Additional results and copies of the computer programs used to generate the results presented in the paper are available from the author at sutirtha.bagchi@villanova.edu.

${ }^{\dagger}$ Sutirtha Bagchi, Assistant Professor, Department of Economics, Villanova University, Villanova, PA, USA (sutirtha.bagchi@villanova.edu). Ph: (610)519-7799 


\section{Introduction}

There is a growing theoretical and empirical literature that examines the effect of politician salary on a variety of measures such as performance of politicians while in office, the decision to run for election, and on the quality of politicians. This paper contributes to that literature by examining the institution of municipal tax collectors in the state of Pennsylvania. These tax collectors are elected officials who are responsible for the collection of property taxes for their respective municipalities. Using two different sources of data on municipal tax collector compensation, this paper finds that an increase in the compensation of tax collectors is associated with an increase in the percentage of property taxes that are collected, but that this relationship holds true only for collectors who are compensated on the basis of a commission and not for collectors compensated on the basis of a salary.

The theoretical literature that examines the effect of politician compensation on the quality and performance of politicians offers ambiguous predictions. Work in the area of efficiency wages suggests that paying workers more reduces shirking because of the higher cost of being fired (Shapiro and Stiglitz 1984) and enhances the quality of the applicant pool (Weiss 1980). These ideas are also central to the model in Besley (2004) which predicts that a higher salary improves the average quality of politicians. Moreover, by increasing the incumbent's payoff from being re-elected, higher compensation also likely spurs better performance on the job.

On the other hand, models such as those in Caselli and Morelli (2004) and Messner and Polborn (2004) start off with the plausible assumption that bad candidates have lower opportunity costs than good candidates and predict that high compensation may induce lower quality candidates to run for election and in equilibrium, reduce the quality of candidates elected. More generally, a literature in personnel economics (Gneezy and Rustichini 2000; Ariely et al. 2009) suggests that workers are often driven by intrinsic motivations and the impact of increasing external rewards might be to reduce the effect of intrinsic motivations via crowd-out. If that is true, increasing politician compensation may have the perverse effect of inducing candidates who are less intrinsically motivated to also run for office. Depending on the voting mechanism at hand, this can reduce the quality of candidates elected in equilibrium. Thus given these ambiguous predictions regarding the effect of politician compensation on quality and performance, the analysis of the effects of compensation of elected officials is an empirical matter.

Examining the relationship between politician compensation and performance empiri- 
cally however runs into a number of challenges. First, since politicians often play a role in deciding on their salaries, one cannot simply estimate the effect of compensation on politician performance without considering the possibility that causality runs in the opposite direction. For example, politicians who demonstrate better performance may be able to get the broader public to support pay raises for them $]^{1}$ Recent papers attempt to overcome this problem either by exploiting large discontinuous changes in policy or by exploiting discontinuities of politicians' salaries with population size. Fisman et al. (2015) and Mocan and Altindag (2013) study politician performance in the European Union, exploiting a pay equalization policy that equalized salaries of Members of the European Parliament (MEP) which had previously differed by as much as a factor of ten. These papers either find no effect of the increase in salaries on attendance and shirking (Fisman et al. 2015) or that it has a negative effect on attendance and the number of questions asked by the parliamentarians (Mocan and Altindag 2013).

Ferraz and Finan (2011) and Gagliarducci and Nannicini (2013) use a regression discontinuity research design that exploits the discontinuous change in salaries of municipal officials with a change in the population of their municipalities in Brazil and Italy respectively. Both papers find that higher salaries attract more educated individuals to run for public office and that more well-compensated politicians appear to have better performance in office. Ferraz and Finan (2011) find that higher wages increase legislative productivity, resulting in more legislative bills and the provision of more public goods. Gagliarducci and Nannicini (2013) find that in municipalities with better-paid mayors, the speed of revenue collection (that is, the ratio between collected and assessed revenue within the year) and the speed of payment (that is, the ratio between paid and committed outlays within the year) is higher.

A few studies have looked at the question of a pay-performance relationship for elected officials in the U.S. context. In one of the earliest analyses, Di Tella and Fisman (2004) examine the variation of gubernatorial salary and estimate that governors experience a pay cut for increases in per capita tax payments and a pay increase for an increase in income per capita in their states. They consider various competing theories but find their results most consistent with a "pay for performance" mechanism. More recently however, a comprehensive study of U.S. governors and state legislators by Hoffman and Lyons (2014) shows little correlation between salary changes and changes in politician performance or quality.

The second empirical challenge in studying the relationship between pay and perfor-

\footnotetext{
${ }^{1}$ Di Tella and Fisman (2004) present suggestive evidence from the U.S. that better economic performance of their states results in higher salaries for governors.
} 
mance of politicians is in constructing credible measures of performance for these officials. Papers exploiting the reform that equalized salaries of MEPs focus on measures such as attendance (Fisman et al. 2015), the number of speeches, written declarations and reports drafted (Braendle 2015), and number of written and oral questions posed by the parliamentarians (Mocan and Altindag 2013). It is debatable whether these proxy measures truly capture the performance of MEPs who are enjoined to "act solely in the public interest and conduct their work with disinterest, integrity, openness, diligence, honesty, accountability and respect for the European Parliament's reputation.'2 Similarly, Ferraz and Finan (2011) examine the number of bills submitted for local legislators across Brazil's municipal governments and the provision of public goods in the areas of education, health, and sanitation, even though nearly 85 percent of the funding for these public goods comes from federal transfers. While the measures used by Gagliarducci and Nannicini (2013) in measuring the performance of Italian mayors (such as the level of capital expenditure and current expenditure, the speed of revenue collection and the speed of payment) are comprehensive and arguably superior to some of the other measures used in the literature, they also suffer from a drawback that they are influenced not just by the actions of the mayor but also by actions and decisions made by the municipal council and the entire municipal bureaucracy.

The relationship analyzed in this paper between pay and performance for municipal tax collectors within Pennsylvania potentially offers a number of advantages over some of these settings. First, we observe considerable variation in both the structure and level of compensation of tax collectors across municipalities. While some municipalities compensate their tax collectors on the basis of a flat salary, others use a commission-based structure. For those municipalities that compensate their tax collectors on a commission basis, there is considerable variation in the percentage of real estate taxes collected paid out as commission which can range from 1 to 5 percent and in some cases, be as high as 10 percent (for the smallest municipalities). Importantly, these variations are largely driven by variations in the codes that enable local government in Pennsylvania such as the Third Class City Code (1931), the Borough Code (1965), the First Class Township Code (1931), the Second Class Township Code (1933), and the Local Tax Collection Law (1945). Although there have been amendments to these codes over the years, the guidelines laid out in the original codes continue to influence the structure of tax collector compensation today. The variation in the compensation of tax collectors results in wide variation in the strength of incentives experienced by tax collectors.

\footnotetext{
${ }^{2}$ Code of Conduct for MEPs available at: http://www.europarl.europa.eu/meps/en/about-meps.html
} 
Few settings in the public-sector demonstrate such considerable heterogeneity in the compensation structure of public officials and one that is not directly influenced by these officials.

Second, we are able to measure the performance of public officials in a manner that is possibly superior to that of prior work. For the tax collectors that we study, their key responsibility lies in collecting real estate taxes for their municipalities (and typically also the school district and county where the municipality is located). We can estimate the performance of these tax collectors on the basis of what percentage of their municipality's predicted real estate taxes they were actually able to collect. Unlike a state's governor or legislators whose actions may have little influence on aggregate economic output of their state (especially over the time horizons typically considered in the literature), a tax collector is likely to have a greater ability to influence the percentage of real estate taxes that are actually collected in their own municipality. Because we are able to generate a measure of their performance, we can also use it to comment on whether voters reward (or punish) a higher collection of property taxes by the tax collector at the ballot box.

Our findings are as follows: Higher compensation is associated with collection of a higher proportion of predicted real estate taxes only for those tax collectors who are compensated on a commission basis in the form of a percentage of real estate taxes collected. There is no statistically significant relationship for tax collectors compensated on basis of a flat salary between their salaries and the percentage of real estate taxes collected. We find no evidence that would indicate that the causal relationship runs in the other direction (from higher performance to higher pay), including undertaking an Instrumental Variables approach which exploits the fact that salaries of elected officials for a given municipality are correlated. Furthermore, we do not find any statistically significant relationship between either the incumbent's decision to run for office or her vote share in the next election cycle and the percentage of taxes collected during the previous term ${ }^{3}$ This suggests that voters do not reward (or punish) higher collection of property taxes by tax collectors and it helps us make sense of the finding that higher pay for salaried tax collectors does not induce a higher level of performance from them.

The paper is laid out in the following sections. Section 2 lays out the institutional setting while Section 3 offers a theoretical model which helps motivate the empirical specifications that follow. Section 4 describes the data sources and presents the econometric specification. Section 5 outlines the results with respect to the relationship between pay and performance

\footnotetext{
${ }^{3}$ The typical term of a tax collector is 4 years long. In some cases, we find terms that are 2 years long. Those are driven by resignations or retirements or deaths. Performance is measured for a 2-year term in such cases.
} 
including a number of robustness checks while Section 6 examines the relationship between the performance in office (measured as the collection rate) and electoral outcomes. I discuss the results and conclude in Section 7.

\section{Institutional Setting}

Pennsylvania has a complex system of local government with the second highest number of local governments in the country, next only to Illinois. General purpose local governments: cities, boroughs, and townships, total approximately 2,600 units. Like local governments around the country, they rely on a mix of revenue sources, including taxes, transfers from higher levels of government, and user-fees and charges. Among those sources, the property tax and the local earned income tax are the two most important sources with each contributing roughly $40-45$ percent of all tax revenue.

Governance of a municipality varies based on the class of municipality and is laid out in the respective codes enabling local government. Municipalities are either classified as cities, boroughs, or townships which can be either of the first class or the second class. Barring the three largest cities - Philadelphia, Pittsburgh, and Scranton, all cities in Pennsylvania are classified as cities of the third class and are governed by a mayor and four councilmen who constitute its governing body. Boroughs have a strong and dominant council and a weak executive (mayor). Townships of the first class are governed by a body of elected commissioners, either five elected at large or up to 15 elected by wards. Townships of the second class are governed by a body composed of three supervisors who are elected at large. Each municipality also has a number of other elected officers with powers that are independent of the city council or borough council or township board. The tax collector is one such elected officer. ${ }^{4}$

As described in the Tax Collector's Manual, "The local tax collector is the municipal officer designated to collect municipal and school real estate and personal taxes levied under the municipal codes, and in most cases, county real estate and personal taxes. In boroughs and second class townships, the office is designated as tax collector; in third class cities and first class townships, the elected treasurer is designated tax collector." This is an elected office; tax collectors are elected for 4-year terms at municipal elections which are held in odd-numbered years in Pennsylvania.

\footnotetext{
${ }^{4}$ There are exceptions to these general principles in the case of home rule municipalities which are allowed to abolish the office of tax collector if that was a part of the charter and approved by voters in a referendum. In such a case, the home rule charter specifies which office is responsible for the collection of municipal property taxes.
} 
The Tax Collector's Manual also describes the minimal qualifications required for candidates for local tax collector. In third class cities, the city treasurer must be a competent accountant, 21 years of age or more, and a resident of the city for a year before the election. An individual does not have to be a certified public accountant; s/he can be a qualified accountant through training and experience. In townships of the first class, the only qualification is being a registered voter of the municipality. In boroughs and townships of the second class, the tax collector must have resided in the municipality for one year before the election and continue to reside there during the term of office..$^{5}$

As was noted earlier, compensation of the tax collector is structured largely based on the codes enabling local government, such as the Third Class City Code and the Borough Code. Within the broad parameters of these codes, the actual compensation of tax collectors is fixed by the local government they collect taxes on behalf of. City treasurers are compensated in the form of an annual salary for collecting taxes. The salary is determined jointly by the city council, school board, and, where applicable, county commissioners. Compensation for treasurers in first class townships is set independently by the taxing districts, typically the municipality, the school district, and the county. Compensation for exercising the responsibilities of the township treasurer is set by an ordinance of the township commissioners with the provision that total compensation for township duties alone cannot exceed $\$ 10,000$ a year. If the commissioners have not established a rate by ordinance, the treasurer receives the statutory rate of 5 percent of taxes collected and 1 percent of other township funds received, subject to the $\$ 10,000$ maximum. Finally, in boroughs and townships of the second class, the compensation for the tax collector is again set by the governing body of the municipality - either the borough council or the board of township supervisors independently of other governmental entities for which collectors may be responsible for collecting property taxes such as the school district and the county. Compensation can be in the form of a salary, wages, or a commission, with total compensation not to exceed 5 percent of the amount of taxes collected for each unit except for second class townships with populations less than 3,000, where it can go up to 10 percent.

As far as fringe benefits are concerned, city treasurers, like city employees, are eligible to participate in life, health, and accident insurance plans purchased by the city and in their retirement plans. Tax collectors in boroughs and townships are however not eligible for fringe benefits such as health insurance which are limited to employees and elected members of the

\footnotetext{
${ }^{5}$ The requirement that tax collectors seek the "Qualified Tax Collector" designation offered by Pennsylvania's Department of Community and Economic Development (DCED) was in effect for a brief period of time between October 2015 and December 2016 which falls outside the time period analyzed in this paper.
} 
governing bodies and the mayor (when one exists). Also, as elected officers, tax collectors in boroughs and townships are generally not eligible for participating in municipal retirement plans. State case law takes the position that the tax collector as an elected officer is not an employee of the supervising governments and is not subject to traditional at-will termination.

\section{Theory}

In this section I lay out a theoretical model which can inform us of whether the method of compensation (salary vs. commission) should matter for the effort exerted by the tax collector (and hence the percentage of taxes collected) and under what circumstances. It can help guide our thinking regarding what we should expect when we regress our performance measure percentage of taxes collected - on various measures of compensation.

Four scenarios are constructed below. These scenarios differ along two dimensions. First, whether the re-election probability for an incumbent responds to the percentage of taxes collected varies across scenarios. Scenarios 1 and 2 consider the case when re-election probabilities do not depend on the percentage of taxes collected whereas scenarios 3 and 4 make the assumption that re-election probabilities are responsive to the percentage of taxes collected during the previous term. Second, the method of compensation (salary versus commission) varies across scenarios. Scenarios 1 and 3 examine the case where the tax collector is compensated on the basis of a salary and scenarios 2 and 4 examine the case where the tax collector is compensated on the basis of a commission.

In the first scenario, characterized as S1, we consider a tax collector compensated on the basis of a salary whose re-election probability does not depend on the percentage of taxes that are collected. The maximization problem for the incumbent tax collector can then be described with help of the following Bellman equation: $\operatorname{Max}_{. e} V=(S-c(e))+\beta *(q * V+(1-q) * 0)$ where $V$ is the value function, $S$ is the salary received, $e$ is the effort exerted, $c(e)$ is the cost of effort (and is an increasing convex function of $e$ ), $q$ is the re-election probability, and the utility for the tax collector if not re-elected is normalized to 0.6 In that case, $V$ simplifies to $V=(S-c(e)) /(1-\beta * q)$.

As with any optimization problem, to maximize $V$ w.r.t. $e$, we set $\partial V / \partial e=0$. Because salary, $S$ and the re-election probability, $q$ are assumed to be unresponsive to effort exerted,

\footnotetext{
${ }^{6}$ Tax collectors are not term-limited and in practice, they do stay in office for multiple terms. Hence our choice to frame this as an infinite-horizon problem.
} 
$e$, this leads to the result that the optimal effort, $e^{*}$ is 0 : that is expected given that neither current period compensation nor re-election probability respond to effort exerted.

In the second scenario, $\mathrm{S} 2$, we consider a tax collector compensated on a commission basis whose re-election probability does not depend on the percentage of taxes that are collected. The maximization problem for that tax collector can be described with the Bellman equation: Max. $_{e} V=(p * T-c(e))+\beta *(q * V+(1-q) * 0)$ where $p$ is the fraction of taxes collected that are paid out in the form of a commission (e.g. 0.05) and $T$ are property taxes actually collected, with the rest of the notations being same as before. In that case, $V$ simplifies to $V=(p * T-c(e)) /(1-\beta * q)$.

To maximize V w.r.t. e, we set $\partial V / \partial e=0$, which leads us to

$$
p * \frac{\partial T}{\partial e}=\frac{\partial c}{\partial e}
$$

That result makes sense: effort is optimal to the point that the marginal benefit of effort (manifested in the form of a higher compensation) equals the marginal disutility from exerting effort. Also, even though the problem is set up as an infinite-horizon problem, its solution is identical to the solution for a single-period optimization because re-election probabilities do not respond to effort. 7

In scenarios 3 and 4 , we introduce the possibility that the re-election probability may respond to effort exerted (and hence percentage of taxes collected). While it may be that tax collectors compensated on a salary are not motivated to exert higher effort as salaries go up if electoral incentives are non-existent, they may be motivated to exert higher effort in a world with electoral incentives. When the re-election probability depends on the percentage of taxes collected, it is reasonable to ask whether that probability goes up or down with an increase in taxes that are collected. Given that the median collection rate of property taxes is about 99\%, it seems safe to assume that from the stand-point of the median homeowner, she would want the tax collector to faithfully collect all taxes that are due. Furthermore, renters would be unambiguously in favor of higher collection rates as they do not directly pay the property tax but benefit from spending on local public goods that are funded through property taxes 8 Consequently, we can expect that the median voter would want to see a higher collection of property taxes and re-election probabilities should be a weakly increasing (concave) function

\footnotetext{
${ }^{7}$ The solution for (3.1) satisfies the SOC because $p * \frac{\partial^{2} T}{\partial e^{2}}-\frac{\partial^{2} c}{\partial e^{2}}<0$, under the plausible assumption that $T$ is a concave function of $e$, while $c$ is a convex function of $e$, as is typically assumed in the literature.

${ }^{8}$ We ignore any second-order effects that result from part of the burden of the tax falling on renters.
} 
of the percentage of taxes that are collected.

Thus, in the third scenario, S3, we assume that the tax collector is compensated on the basis of a salary but her re-election probability depends on the percentage of taxes collected. The maximization problem is given by the identical Bellman equation as in $\mathrm{S} 1: M a x_{e} V=$ $(S-c(e))+\beta *(q * V+(1-q) * 0)$ where notations are as defined earlier. However, now re-election probability, $q$, goes up with an increase in effort, $e$, i.e. $\partial q / \partial e>0$. As before, $V=(S-c(e)) /(1-\beta * q)$ but now when we set $\partial V / \partial e=0$, we no longer obtain the result that the optimal level of effort is zero. Instead we obtain:

$$
\frac{\partial c}{\partial e}=\frac{\beta}{(1-\beta * q)} *(S-c(e)) * \frac{\partial q}{\partial e}
$$

Thus, effort is exerted to the point that it makes a difference to the "rents" from being reelected; the rents obtained from being a collector $(S-c(e))$ are multiplied with the responsiveness of the re-election probability to effort $\left(\frac{\partial q}{\partial e}\right)$ and a factor that sums up these rents from the second period of the model till eternity $\left(\frac{\beta}{(1-\beta * q)}\right){ }^{9}$ Hence when re-election probabilities go up with effort, a salaried tax collector will exert positive effort even though her current-period compensation does not respond to effort.

Finally, in the fourth scenario, S4, we assume that the tax collector is compensated on a commission basis but as in $\mathrm{S} 3$, re-election probability depends on the percentage of taxes collected. The maximization problem now is given by the identical Bellman equation as in S2: $\operatorname{Max}_{.} V=(p * T-c(e))+\beta *(q * V+(1-q) * 0)$ where notations are as defined earlier but where $\partial q / \partial e>0$. As before, $V=(p * T-c(e)) /(1-\beta * q)$. To maximize $\mathrm{V}$ w.r.t. e, we set $\partial V / \partial e=0$ and now obtain that:

$$
\frac{\partial c}{\partial e}=p * \frac{\partial T}{\partial e}+\frac{\beta}{(1-\beta * q)} *(p * T-c(e)) * \frac{\partial q}{\partial e}
$$

Here, the expression follows from what we have seen earlier in scenarios 2 and 3: exerting effort results in a benefit both in the current period - through a higher compensation - but also in subsequent periods through an increase in the re-election probability. The second term of the above expression on the RHS closely parallels the term we see in (3.2), with the difference that the tax collector's compensation in Scenario 3 is in the form of a salary whereas here in Scenario 4, it is in the form of a commission.

\footnotetext{
${ }^{9}$ One may ask why these rents are not dissipated through electoral competition. Explaining that is beyond the scope of this paper but may have to do with an incumbency advantage. See also fn. (13).
} 
What the theoretical discussion helps illuminate is that dynamic motives may induce a tax collector compensated on a salaried basis to exert more effort as salary goes up, as exerting more effort (and hence collecting more in taxes) may lead to an increase in the probability of being re-elected. In our results section, we will therefore examine the responsiveness of various proxies of re-election probabilities to the percentage of taxes collected between two consecutive elections. In passing, we also note (and prove formally in the Appendix) the intuitive result that increasing compensation has the effort of increasing the optimal effort chosen, when collectors are compensated on basis of a salary (as long as dynamic motives are present) or when compensated on a commission basis (under all circumstances).

\section{Data Sources and Empirical Specification}

\subsection{Data Sources}

I utilize a variety of data sources for this study. There are two sources of data on compensation of tax collectors. The first comes from a 2004 survey conducted by the Pennsylvania Economy League (PEL) of municipalities in nine counties in central and eastern Pennsylvania regarding their tax collection practices. Details of the survey conducted by the Pennsylvania Economy League (PEL) are provided in the Appendix.10 The second source of data on compensation is the Pennsylvania Manual, a comprehensive guide to Pennsylvania's government. Each edition of the Manual provides information on the compensation of tax collectors from approximately 130 of the largest municipalities within Pennsylvania.

There are a number of advantages of the data included in the 2004 survey by the PEL. First, they include compensation data on a larger number of municipalities compared to the number of municipalities included in the Pennsylvania Manual. Second, because it includes data on a number of smaller municipalities (generally boroughs and townships of the second class), we find more instances in the data where tax collectors are compensated on a commission basis rather than on the basis of a flat salary. Moreover, there is considerable variation in the percentage of real estate taxes paid to the tax collector as compensation in that sample. Data from the Pennsylvania Manual, on the other hand, pertains to the largest municipalities (predominantly cities and townships of the first class) and tax collectors in these municipali-

\footnotetext{
${ }^{10}$ The response rate to the survey was $74 \%$. I examine if non-response is systematically correlated with the millage rate of the municipality and the market value of real estate per capita but there is no such evidence. As such, any bias induced by non-response seems not to be of first-order importance.
} 
ties are more likely to be compensated in the form of a flat salary. Furthermore, in a number of instances, townships of the first class bunch at the $\$ 10,000$ cap imposed by the First Class Township Code. There is however one advantage of the Pennsylvania Manual data: these are available over time making it possible for us to construct a panel.

In order to obtain a sense of the efficiency of the property tax collection system at the municipal level, I turn to data on municipal finances available from the Pennsylvania Department of Community and Economic Development (DCED). The data most relevant to us pertain to the assessed value of real estate, the millage rate chosen by the municipality, and real estate taxes that were actually collected. We can use these data to define a measure of performance, the percentage of real estate taxes collected as:

$$
\text { Percentage of real estate taxes collected }=\frac{\text { Real estate taxes collected }}{(\text { Millage rate } / 1000 * \text { Assessed Value of Real Estate })} * 100
$$

For example, consider Lower Merion Township in Montgomery County. For 2007, their tax rate on the assessed value of a property was 3.54 mills and the total assessed value of real estate was $\$ 7,446,874,345$. Thus the real estate taxes that should have been collected for the year equal $\$ 26,361,934$. However, $\$ 26,203,727$ was actually collected, suggesting that 99.4 percent of the taxes that should have been collected were actually collected. The percentage of real estate taxes collected, averaged over the term of a tax collector, is the dependent variable included in the analysis where I examine the existence of a relationship between pay and performance. It is also worth pointing out that the millage rate is decided by the governing body of the municipality (typically, a City Council or a Borough Council or a Township Board of Supervisors) while a board appointed by the county ("Board of Property Assessment, Appeals and Review") decides on the assessed value of real estate. The tax collector however is in charge of mailing tax bills, collecting payment, following up on delinquent taxpayers and therefore plays a unique role in influencing the percent of real estate taxes that are being actually collected by the municipality.

The last source of data I use pertain to elections for tax collectors. These are available from the websites of the Boards of Elections for the counties in which the municipalities are located. Election data prior to the early to mid-2000s are typically not available in electronic form. I pick 2003 as the starting point and look for which of Pennsylvania's 67 counties have data on elections available electronically with the County Boards of Elections. Ultimately I am able to obtain data from sixteen counties that have election data for the period between 
2003 and 2009. These data are then subsequently matched with the data on tax collector performance to examine if performance in office has any relationship with the likelihood of an incumbent tax collector being re-elected and other proxies that capture electoral incentives.

Summary statistics are presented in Table 1.

\section{[Table 1 about here.]}

Table 1 clearly indicates the wide variation in the compensation of tax collectors across municipalities. Additionally, one can also discern wide differences in compensation based on the two sources - the 2004 PEL survey and the Pennsylvania Manual. These differences primarily reflect the differences in size of the municipalities covered by the two sources. The largest municipalities which are included in the Pennsylvania Manual are more likely to pay their tax collectors (or treasurers) higher salaries than the smaller municipalities, which are more likely to appear in the PEL survey. The largest municipalities are also much more likely to pay on the basis of a flat salary than on a commission basis.

Table 1 also indicates that collection rate of property taxes is very high, reflecting the high compliance associated with the property tax ${ }^{11}$ We also observe collection rates that are occasionally higher than 100 percent. This is partly explained by the fact that in some instances, a large owner of property who was delinquent in a particular year may pay in a subsequent year causing the collection rate for that year to go above 100 percent. Additionally, this is affected by how and when penalties get assessed. Bills paid prior to April 30 of each year qualify for a two percent discount whereas a ten percent penalty is assessed for payments made after July 1. Therefore, even when taxes are paid within the same year that they are assessed, they may incur a penalty if payments are made after July 1st. Lastly, statistical discrepancies in the data on municipal finances available from the Department of Community and Economic Development also play a part.12 On account of these reasons, in all our estimations we only use observations that lie within the 5 th and 95 th percentile of the distribution for percent real estate taxes collected.

\footnotetext{
${ }^{11}$ The article, http://www.philly.com/philly/news/politics/mayor/How_to_fix_Phillys_poor_tax_collection_delinquincy for example, notes that the property tax delinquency rate for the city of Philadelphia was 6.2 percent, almost double the average for big American cities, and yet "other city tax streams have even worse compliance rates."

${ }^{12}$ Considerable effort was taken in cleaning the data prior to use. I conducted a web search for county/ municipal Comprehensive Annual Financial Reports (CAFRs) to verify the millage rates and assessed values of real estate. I consulted newspaper archives available through the ProQuest platform to look for any articles referencing changes in millage, property taxes, or collection rates for municipalities. Finally, I also looked through minutes of meetings for City Councils, Borough Councils, and Township Boards for any information on budgets, real estate taxes, and millage rates that would help corroborate or alter any of the data provided in the Municipal Finance Statistics. These examinations were undertaken intensively for values of percent taxes collected that fell beyond a "reasonable" range from 90 - 110 percent.
} 


\subsection{Empirical Specification}

There are two analyses undertaken to examine the research questions of interest and I lay out the empirical specification used for each.

First, to examine if there is a relationship between tax collector compensation and their performance, I look at the percentage of predicted real estate taxes that were actually collected by the municipality. As there is considerable year-to-year variation, I consider the average over a multiple-year window. When using the 2004 data on compensation from the PEL survey, I consider an average of the percentage of real estate taxes collected for the subsequent four-year period from 2005 through 2008. The specification used is:

$$
Y_{i t}=\alpha+\beta * C_{i(t-1)}+\gamma * W_{i t}+\varepsilon_{i t} .
$$

In the equation above, $Y_{i t}$ is the percentage of real estate taxes actually collected over a 4-year window between $\mathrm{t}$ and $(\mathrm{t}+3), C_{i(t-1)}$ refers to compensation at the start of that 4-year window, $W_{i t}$ includes municipal-level controls that are likely to have an independent influence on the efficiency of the property tax collection system, and $\varepsilon_{i t}$ is the error term. In the case of tax collectors who are compensated on a commission basis, $C$ refers to the percentage of real estate taxes paid as commission while in the case of tax collectors who are compensated on the basis of a salary, $C$ refers to the log of annual salary.

To examine whether a higher collection of property taxes is rewarded (or punished) by voters, I examine two different margins. I first examine whether the incumbent is more or less likely to run based on her performance in office. In case the incumbent decides to run again for office, I examine whether the collection rate during the period she was in office influences her vote share ${ }^{13}$ With both dependent variables, I include the lagged vote share from the previous electoral cycle in half of the specifications, while in the remaining, I run a simpler specification that does not control for the lagged vote share. When the lagged vote share is controlled for, the specification used is as follows:

$$
V_{i t}=\alpha+\beta * P_{i(t-1)}+\gamma * V_{i(t-4)}+\varepsilon_{i t} .
$$

In the equation above, $V_{i t}$ is the current vote share of an incumbent tax collector, $V_{i(t-4)}$ is the lagged vote share of the incumbent, $P_{i(t-1)}$ is the percentage of real estate taxes actually

\footnotetext{
${ }^{13}$ One could examine whether the incumbent wins or loses if she decides to run again, but in our dataset there are only two instances (out of 543 possible) where the incumbent loses her race. Therefore, we cannot meaningfully seek to explain variation in the likelihood of the incumbent winning an election based on her performance in office and instead seek to examine these other margins, which may also be influenced by her performance.
} 
collected over a 4-year window between (t-3) and $t$, and $\varepsilon_{i t}$ is the error term ${ }^{14}$ This analysis is conducted using data on all elections held between 2003 and 2009 for all sixteen counties from the state for which such data were available.

\section{Results}

\subsection{Does higher compensation induce the collection of more taxes?: Evi- dence from the PEL data}

Table 2 presents the results of analyzing the PEL data using specification (4.1). Panel A of Table 2 uses observations from municipalities which compensate their tax collectors on a commission basis while Panel B of Table 2 includes municipalities where tax collectors are compensated on the basis of a flat salary. Column (1) of both panels estimates a parsimonious specification with no controls. Column (2) adds controls for the millage rate as well as the $\log$ of market value of real estate per capita, as these variables may have an independent influence on the percentage of real estate taxes that are actually collected. For example, a low market value of real estate per capita is likely in municipalities experiencing a challenging economic environment and it may be harder to collect real estate taxes in such a municipality. Columns (3) and (4) replicate columns (1) and (2) but add in county fixed effects as well.

\section{[Table 2 about here.]}

When we consider the effect of a higher compensation in Panel A of Table 2 where our analysis is limited to those municipalities which pay their tax collectors on a commission basis, we find a positive and statistically significant relationship between the compensation received by tax collectors and the percentage of real estate taxes that are actually collected. This is true across the four columns of the table as progressively more controls are added. Although the coefficients are statistically significant in all cases, the magnitude of the coefficient is well below 1 suggesting that, on average, a compensation policy that incentivizes tax collectors with a higher percentage of taxes collected may not ultimately benefit the tax coffers of the municipality. Subsequently when we examine only municipalities which pay their tax collectors a fixed salary in Panel B of Table 2, we do not find a statistically significant effect of compensation on the percentage of real estate taxes that are actually collected. These results

\footnotetext{
${ }^{14}$ Of the 731 decisions to run for office in the sample, about $85 \%$ of those involved a full 4-year term. For the roughly $15 \%$ of observations that involved a 2 -year term, those are likely to have been driven by deaths, resignations, or removal from the office of the tax collector. In those cases, the percentage of real estate taxes collected is averaged over the 2 -year term during which the incumbent was in office.
} 
in Panel B of Table 2 suggest that increasing salaries of tax collectors does not induce them to collect a higher fraction of real estate taxes that are due.

\subsection{Does higher compensation induce the collection of more taxes?: Evi- dence from the Pennsylvania Manual data}

Data from the Pennsylvania Manual are next used to examine the relationship between pay and performance for tax collectors. Tables 3 and 4 mimic the pattern of Panels A and B of Table 2 with Table 3 including municipalities that compensate on the basis of a commission while Table 4 examines municipalities that compensate on the basis of a salary. As was described earlier, data from the Pennsylvania Manual pertain to the largest municipalities within the state and nearly all of these municipalities pay their tax collectors a fixed salary. Depending on the vintage of data from the Pennsylvania Manual, anywhere between 13-31 municipalities in this dataset rely at least partly on a commission-based structure, but of those, we know the level of the commission for less than a third of the municipalities (an average of 6 per year). The paucity of observations from the Pennsylvania Manual involving commissionbased compensations makes it less meaningful to estimate a regression that includes county or municipality fixed effects in Table 3 (unlike Table 4) 15 We therefore only present results from specifications which pools observations from all counties across all vintages of the Pennsylvania Manual.

[Table 3 about here.]

[Table 4 about here.]

The findings in Tables 3 and 4 parallel the findings from Table 2. When we limit our analysis to municipalities which pay their tax collectors on a commission basis, we find a positive and statistically significant relationship between the compensation received by tax collectors and the percentage of real estate taxes that are actually collected. Although the coefficients on the commission rate in Table 3 are substantially higher than the coefficients in Panel A of Table 2, these coefficients are not statistically different from each other. Also, the coefficients on the commission rate in Table 3 continue to be less than 1 suggesting again

\footnotetext{
${ }^{15}$ The results in Table 3 use 34 observations (each observation is a municipality-year combination) that are spread across 13 counties. Introducing county fixed effects, therefore swamps out much of the variation leaving little to be explained. We still obtain positive coefficients with such a specification but the coefficients are no longer statistically significant.
} 
that a compensation policy that incentivizes tax collectors with a higher percentage of taxes collected would not increase the net revenue for municipal governments.

Based on the results in Table 4, we do not find a statistically significant relationship between compensation and percentage of real estate taxes actually collected when only municipalities that compensate on a salaried basis are included in the estimation suggesting the lack of a pay-performance relationship for these collectors. This is true regardless of whether we pool across all municipalities (cols. (1) and (2)) or introduce county fixed effects (cols. (3) and (4)) or municipal fixed effects (cols. (5) and (6)), something made possible because of the panel nature of the data. Since the estimation pools data from multiple issues of the Pennsylvania Manual spread over two decades, we also look at whether this relationship holds true for each cross-section of the data and confirm that the lack of a relationship between pay and performance holds in each cross-section. Those additional results are available on request.

\subsection{Robustness checks for results involving relationship between pay and performance}

In this section, we present a number of robustness checks for the result that there is a positive relationship between pay and performance for tax collectors paid on a commission basis, while no such relationship exists for tax collectors paid a salary.

First, although the vast majority of tax collectors are elected officials, in a small proportion of municipalities, we find tax collectors who were appointed to their office. The most common reason for why we might find an appointed (rather than an elected) tax collector is because municipalities can adopt a home rule charter and several such charters have done away with the elected office of the tax collector, instead appointing a civil servant to collect property taxes for their municipality ${ }^{16}$ Given the literature (e.g. Besley and Coate (2003) who find that states with elected regulators adopt more pro-consumer regulatory policies or Whalley (2013) who finds that appointed city treasurers in California reduce a city's cost of borrowing), an interesting angle to explore using these data is whether elected and appointed tax collectors respond differently to incentives. This analysis is however possible only with the Pennsylvania Manual data since the PEL survey data by design excludes compensation

\footnotetext{
16“A municipality which has adopted a home rule charter may exercise any powers and perform any function not denied by the Constitution of Pennsylvania, by statute or by its home rule charter. All grants of municipal power to municipalities governed by a home rule charter under this subchapter, whether in the form of specific enumeration or general terms, shall be liberally construed in favor of the municipality." (http://www.legis.state.pa.us/WU01/LI/LI/CT/HTM/53/00.029..HTM)
} 
data for appointed tax collectors ${ }^{17}$ Table 5 presents these results. The split by appointed versus elected tax collectors however illustrates that the lack of a positive relationship between pay and performance for salaried tax collectors holds separately for the sample of elected tax collectors (Panel A) and the sample of appointed tax collectors (Panel B).

\section{[Table 5 about here.]}

Second, rather than using one observation per four-year period (the typical term in office) and the average percentage taxes collected during that period, in this robustness check, we exploit the fact that data on municipal finances are available on an annual basis from the Department of Community and Economic Development. Using the annual nature of these data, we re-examine the relationship between tax collector compensation and the percentage of taxes collected in each year of the sample period. The results are included as Appendix Tables A.1 (for the PEL survey) and A.2 and A.3 (for the Pennsylvania Manual) and indicate that our conclusions are not sensitive to whether we use four-year averages of the percentage taxes collected or their annual values. Using the annual nature of the data also lets us examine for the presence of any "political budget cycles" or tax collection rates varying in any systematic manner over the term of a tax collector in office but there is no evidence suggesting such cycles in tax collection.

As was noted earlier, the office of city treasurers appears to be qualitatively different from the office of treasurers in townships of the first class or tax collectors in boroughs and townships. City treasurers are eligible for health insurance, pension benefits, and other fringe benefits from their employers and therefore the salary they receive reflects only a portion of their total compensation. Hence, I repeat the entire analysis reported in Table 4 but distinguish cities from other classes of municipalities. The results obtained by limiting myself to boroughs and townships (both of the first class and the second class) are presented in Panel A of Appendix Table A.4 with the results for cities presented in Panel B of the same table. Our conclusion that there is no evidence of a positive relationship between pay and performance holds in both sub-samples.

Another concern that we address is that the relationship rather than going from pay to

\footnotetext{
${ }^{17}$ The data made available for this study from the PEL had been collected in 2004 as part of a benchmarking study to inform municipalities of how their costs of tax collection compared with other municipalities in their counties. PEL had the view that there was substantial opportunity for making significant cuts in real estate tax collection costs but given that taxing jurisdictions are prohibited from reducing the compensation during the term of office for an incumbent tax collector, it collected and distributed these data in October 2004 prior to the filing of nominations for municipal elections in 2005. By design, the PEL survey therefore excluded municipalities which had eliminated the elected office of the tax collector.
} 
performance, runs in the other direction. In other words, higher performance might induce higher commission rates, rather than higher commission rates inducing higher performance. In order to examine this hypothesis, we need panel data which therefore rules out the use of the PEL survey data. The panel nature of the data from the Pennsylvania Manual makes it possible to examine this relationship but only for municipalities that compensate their collectors with a salary given that few municipalities in this dataset compensate their tax collectors on a commission basis and we know the commission rate for less than a third of those municipalities. As long as it is the case that the political forces which induce higher compensation for tax collectors with better collection rates apply to municipalities regardless of whether they pay on a commission basis or on the basis of a salary, examining the performance-pay relationship for municipalities compensating on the basis of a salary is informative of the performance-pay relationship for municipalities using a commission-based system. In the regressions presented in Table 6 we consider a variety of approaches and functional forms; we examine if either the level or changes in salary can be predicted based on the lagged level of percent real estate taxes collected or based on the lagged change in the percent real estate taxes collected. We also consider salary, in log terms (in columns (1) through (4)) and in absolute terms (in columns (5) through (8)).

[Table 6 about here.]

Regardless of the functional form or the empirical approach used, we do not find any evidence of a positive performance-pay relationship for tax collectors who are compensated on a salaried basis as the coefficients of interest are statistically indistinguishable from zero in all specifications. As noted above, while this does not let us directly rule out the possibility that a positive performance-pay relationship might exist for collectors compensated on a commission basis (which therefore results in the observed positive relationship between pay and performance), that appears to be unlikely.

A final approach we present to also assure readers that there is no positive relationship between tax collector compensation and measures of performance for collectors who are compensated on a salary basis is to use an instrumental variables (IV) approach. In this case, an ideal instrument will be correlated with tax collector compensation but will not have any direct effect on the percentage of taxes collected in a municipality, other than indirectly through tax collector compensation.

In our search for a possible instrument, we turn again to the Pennsylvania Manual and 
exploit the idea that salaries of elected officials for a given municipality are likely to be correlated. Although tax collector compensation is largely determined by the codes enabling local government (and is unaffected by performance as suggested by results in Table 6), it seems plausible that the compensation of the tax collector is correlated positively with compensation of other elected officials in that municipality. Salaries of council members and other elected officials like the tax collector are not entirely immune to fluctuations in the size of the municipal budget and demographic or other characteristics (such as a more affluent population or a large commercial real estate base) may support salaries for a given municipality that are higher than what would be predicted based simply on a municipality's population and its type ${ }^{18}$ At the same time, there are few reasons to suspect that members of the governing body of a municipality would be able to directly influence the percentage of real estate taxes that are collected. Although council members are responsible for setting the millage rate, following up on delinquent taxpayers is the sole responsibility of the tax collector. In rare instances when property sales are held to recover taxes owed by severely delinquent taxpayers, such sales are organized and conducted by the counties in which those properties are located ${ }^{19}$ On this basis, we use salary of the highest paid member of a municipality's governing body (typically, the Mayor or the Council President or the Chairman) as an instrument for tax collector compensation that plausibly meets both the relevance and validity considerations. 20

In Appendix Table A.5, we present the results from this IV approach where the first-stage involves regressing the log of tax collector compensation on the log of salary for the highest paid member of that municipality's governing body and the second-stage involves using the predicted value to look for the presence of any relationship between pay and performance for tax collectors. As can be seen from the coefficients on the log of salary in Panel A of the table, there is no evidence of a positive relationship between tax collector compensation and performance. The instrument also appears to be relevant as we get a first-stage F-statistic on the excluded instrument that exceeds the critical value of 10 suggested by Stock, Wright, and Yogo (2002) in all but one of the specifications. The results in Tables 6, A.5, along with the

\footnotetext{
${ }^{18}$ If there is a bias that is induced in the regressions through this correlation between demographics and tax collector compensation, the bias should lead to a positive correlation between salaries and measures of performance. In other words, high salaries would lead to a higher percentage of real estate taxes being collected because delinquencies in paying property taxes are likely to be low in more affluent areas. Clearly, the results presented in Table 4 do not support a positive relationship between tax collector compensation and performance and hence any bias that might be induced is likely not to be particularly important in our context.

${ }^{19}$ See for example, http://www.eriecountypa.gov/media/439714/saleinfo_2016_-rev071816.pdf and http://www.reageradlerpc.com/articles-resources/article/10-10-27/Real_Estate_Investing_Understanding_PA_Tax_Sales.aspx

${ }^{20}$ Results are very similar if we use the salary of the second highest paid member of the municipality's governing body and are available on request.
} 
institutional context give us some confidence that the positive relationship between pay and performance for collectors compensated on a commission basis is unlikely to be simply driven by reverse causality.

\section{Does higher percent collection while in office impact the likelihood of being re-elected?}

One of our findings is the lack of a statistically significant positive relationship between pay and performance for tax collectors who are compensated on a salaried basis. In other words, a higher salary does not induce such tax collectors to exert more effort and collect a higher share of taxes that are owed to the municipality. This is contrary to the notion of efficiency wages which suggests that paying workers more reduces shirking because of the higher cost of being fired (Shapiro and Stiglitz 1984) and the model in Besley (2004) which suggests that by increasing the incumbent's payoff from being re-elected, higher compensation likely spurs better performance on the job. What might help reconcile our findings with the theory of efficiency wages is the lack of electoral incentives; in other words, if voters appear not to reward a higher collection of property taxes by tax collectors at the ballot box then higher salaries may not elicit higher performance.

In order to examine the question of whether better performance by tax collectors induces electoral rewards from voters, we turn to data on elections for the office of tax collector. We narrow our search to elections that were held between the years 2003 and 2009 as the performance measure - percentage of taxes collected - can be constructed for this time period and because prior to the $2000 \mathrm{~s}$, it is difficult to obtain local election data. Drawing on data available from the various county Boards of Elections, we are able to observe 726 municipalities spread across sixteen counties at least once over the sample period ${ }^{21}$ For the municipalities for which we have data, we observe more than one election for 714 municipalities ${ }^{22}$ In order to see if voters reward higher collection of taxes by tax collectors at the ballot box, an obvious dependent variable of interest would be the re-election probability for an incumbent tax

\footnotetext{
${ }^{21}$ These counties are spread across Pennsylvania and include Berks, Butler, Centre, Fulton, Lancaster, Lehigh, Luzerne, Mercer, Monroe, Montgomery, Northampton, Pike, Schuylkill, Venango, Washington, and Westmoreland.

${ }^{22}$ Even though our election data span a 6-year period from 2003 and 2009 and the term of office of a tax collector is only 4 years, we observe election results only once for 12 of the 726 municipalities. The primary reason for the drop-off is because in some municipalities no one may have formally run for the office in a particular electoral cycle and in that case the municipality would have delegated the task of collecting taxes to someone. Such appointments and delegations (decisions made by the city council or the borough council or the township board) are not captured in our data.
} 
collector and analyzing how that varies based on performance in office. However, as the summary statistics in Table 1 indicate, the probability that an incumbent tax collector running for office is re-elected is very high at 0.996 and therefore we cannot meaningfully comment on how re-election probabilities respond to performance in office ${ }^{23}$ In the absence of that, we turn to other proxies of electoral rewards in Table 7.

We first examine the decision of an incumbent to run for office again. This is based on the idea that if voters reward incumbents for collecting a higher percentage of real estate taxes, then they would be more likely to run for office again. While factors such as health and age undoubtedly play a role in the decision of an incumbent tax collector to not run for office again, a literature in political science suggests that politicians retire strategically at higher rates when they expect a challenging race. ${ }^{24}$ Panel A of Table 7 therefore presents the results of a probit which examines whether the likelihood of an incumbent running for office again is influenced by her performance or not. This is defined only for the municipalities where we observe the choice of the incumbent tax collector to either run again or step down from office, that is for all elections but the last election in our sample for a given municipality. We examine if this decision is responsive to the percentage of real estate taxes collected between the two election cycles.

In Panel B of Table 7, we examine how the incumbent tax collector's vote share in an election cycle is influenced by her performance in the previous term in office for races where she faces off against an opponent. Few elections to the office of tax collector are contested in practice and hence this measure is defined only for the 42 cases where we find that the incumbent decides to run again for office and faces an opponent. In column (1), we consider the most parsimonious specification and only include our key independent variable, the percentage of taxes collected during the last term in office. ${ }^{25}$ Column (2) adds in a control for the lagged vote share as it is likely that the vote share of candidates is correlated over time because of party allegiances of voters and because of candidates' reputations. Columns (3) and (4) parallel columns (1) and (2) but they add in county fixed effects.

[Table 7 about here.]

\footnotetext{
${ }^{23}$ In only two out of 543 possible instances do we observe an incumbent tax collector lose her election.

${ }^{24}$ Stone et al. (2010) for example show in the context of elections to the U.S. House that incumbent retirement is sensitive to their prospects for reelection.

${ }^{25}$ About $85 \%$ of the observations involves a full 4 -year term while the remaining $15 \%$ involve a 2 -year term. In such cases, the percentage of real estate taxes collected is averaged over the 2-year term during which the incumbent was in office.
} 
Based on the results in Panel A, we observe that the decision of the incumbent to run for office again is not influenced by her performance in office, measured as the percentage of real estate taxes collected between the two electoral cycles. It also does not seem to be influenced by the percentage of votes she received in the previous election. We obtain similar results as those in Panel A when we use a linear probability model (LPM) or retain a probit specification but include municipal population as an additional control. Results from those additional specifications are presented in Appendix Table A.6.

The results in Panel B of Table 7 when we limit ourselves to those races where there was a contest in the general election suggest that the vote share of incumbents does not respond to the percent of taxes collected in the period between the two election cycles as our coefficient of interest is statistically insignificant in three of the four columns and marginally significant (at the 10\% level) in one of the columns. The lagged vote share of the incumbent is positive in both columns (2) and (4) (but statistically significant only in (2)) suggesting some persistence in vote shares over successive elections, 26

Overall, based on the descriptive evidence regarding the incumbency advantage, the results presented in Tables 7 and A.6, we can conclude that voters are unlikely to reward (or punish) tax collectors for their performance in office and therefore electoral considerations are unlikely to influence decisions by the tax collector of how much effort to exert. These results may therefore offer a possible explanation for our earlier finding that the performance of salaried tax collectors does not go up with an increase in their salary.

\section{Discussion and Conclusions}

This paper presents one of the first analyses of whether a pay-performance relationship exists for elected municipal officials in the United States. Using data on percentage of real estate taxes that are actually collected, the paper suggests that municipal tax collectors who are paid on a commission basis collect more in property taxes as the commission they receive goes up. In contrast, there appears to be no statistically significant relationship for tax collectors who are compensated on the basis of a flat salary. This final observation can perhaps be partly explained by the fact that voters do not seem to reward performance in office, as measured by

\footnotetext{
${ }^{26}$ As columns (1) through (4) of Panel B of Table 7 indicate, we use only 40 observations (and not 42). The reason for the drop-off is that given the large dispersion in the independent variable, percentage of taxes collected, some of which is undoubtedly due to measurement error, we limit our estimations to those observations for which the independent variable falls between the 5 th and 95 th percentile of the underlying distribution.
} 
the percentage of taxes that are collected. The incumbent's likelihood of running for office and her vote share are not significantly influenced by the percentage of real estate taxes collected between two successive electoral cycles.

Commenting on the welfare implications of tax collectors collecting more in property taxes when compensated on the basis of a commission is tricky as it involves comparing the marginal benefit of a dollar in private hands with the marginal benefit of a dollar in the hands of the government. That, in turn, is likely to hinge on one's views of government: whether one views it as a benevolent maximizer of social welfare or as a Leviathan, ala Brennan and Buchanan (1980). Tax collectors compensated on a commission can also end up being overzealous, a fact that undoubtedly contributed to the elimination of the practice of "tax farming" and a sea change in the structure of their compensation over time across most geographies (White 2004; Parrillo 2013).

Commenting on the revenue implications for local governments is easier. Given the evidence presented in this paper using two different datasets, including the IV approach used with the Pennsylvania Manual data, we can rule out the possibility that higher salaries induce higher performance. Although higher commission rates appear to induce more tax collection, given the magnitude of the coefficients on the commission rate which are uniformly less than 1 across both datasets, a municipality would likely receive less net revenue if it were to increase the commission rate of its tax collectors. This result however may not generalize to other settings: compliance levels with the property tax are very high to begin with and there may be limited room to increase compliance rates further with high-powered incentives.

The work described in the paper sheds some light on the question of whether and how incentives matter in the public sector. Further work on examining the institution of municipal tax collectors would benefit from additional data regarding the compensation that they receive for collecting school district and county taxes beyond what they receive from the municipality for which they collect property taxes. We would also benefit from examining other settings where we can construct credible measures of the performance of these officials and where we can comment on the quality of elected officials, as measured by their educational background or prior relevant work experience. Finally, it would be of interest to explore the effect of highpowered incentives in other contexts where compliance rates are lower than what we observe here. 


\section{References}

Ariely, Dan, Anat Bracha, and Stephan Meier, "Doing Good or Doing Well? Image Motivation and Monetary Incentives in Behaving Prosocially," American Economic Review, 2009, 99(1), 544-555.

Besley, Timothy, "Paying Politicians: Theory and Evidence," Journal of the European Economic Association, 2004, 2(2-3), 193-215.

Besley, Timothy and Stephen Coate, "Elected versus Appointed Regulators: Theory and Evidence," Journal of the European Economic Association, 2003, 1(5), 1176-1206.

Braendle, Thomas, "Does remuneration affect the discipline and the selection of politicians? Evidence from pay harmonization in the European Parliament," Public Choice, 2015, $162,1-24$.

Brennan, Geoffrey and James M. Buchanan, The Power to Tax, (Cambridge: Cambridge University Press, 1980).

Caselli, Francesco and Massimo Morelli, "Bad Politicians," Journal of Public Economics, 2004, 88(3-4), 759-782.

Di Tella, Rafael and Raymond Fisman, "Are Politicians Really Paid Like Bureaucrats?" Journal of Law and Economics, 2004, 47(2), 477-513.

Ferraz, Claudio and Frederico Finan, "Motivating Politicians: The Impacts of Monetary Incentives on Quality and Performance," Working Paper, 2011.

Fisman, Raymond, Nikolaj Harmon, Emir Kamenica, and Inger Munk, "Labor Supply of Politicians," Journal of the European Economic Association, 2015, 13(5), 871-905.

Gagliarducci, Stefano and Tommaso Nannicini, "Do Better Paid Politicians Perform Better? Disentangling Incentives from Selection," Journal of the European Economic Association, 2013, 11(2), 369-398.

Gneezy, Uri and Aldo Rustichini, "Pay enough or don't pay at all," The Quarterly Journal of Economics, 2000, 115(3), 791-810.

Hoffman, Mitchell and Elizabeth Lyons, "Do Higher Salaries Lead to Higher Performance? Evidence from State Politicians,” Working Paper, 2014.

Messner, Matthias and Mattias K. Polborn, "Paying Politicians," Journal of Public Economics, 2004, 88 (12), 2423-2445.

Mocan, Naci H. and Duha T. Altindag, "Salaries and Work Effort: An Analysis of the European Union Parliamentarians," Economic Journal, 2013, 123(573), 1130-1167.

Parrillo, Nicholas R., Against the Profit Motive: The Salary Revolution in American Government, 1780-1940 (New Haven, CT: Yale University Press, 2013).

Shapiro, Carl and Joseph Stiglitz, "Equilibrium Unemployment as a Worker Discipline Device," American Economic Review, 1984, 74(3), 433-444. 
Stock, James H., Jonathan H. Wright, and Motohiro Yogo, "A Survey of Weak Instruments and Weak Identification in Generalized Method of Moments," Journal of Business and Economic Statistics, 2002, 20 (4), 518-529.

Stone, Walter J., Sarah A. Fulton, Cherie D. Maestas, and L. Sandy Maisel, "Incumbency Reconsidered: Prospects, Strategic Retirement, and Incumbent Quality in U.S. House Elections," The Journal of Politics, 2010, 72(1), 178-190.

Weiss, Andrew, "Job Queues and Layoffs in Labor Markets with Flexible Wages." Journal of Political Economy, 1980, 88(3), 526-538.

Whalley, Alexander, "Elected versus Appointed Policy Makers: Evidence from City Treasurers," The Journal of Law and Economics, 2013, 56(1), 39-81.

White, Eugene N., "From Privatized to Government-Administered Tax Collection: Tax Farming in Eighteenth-Century France," Economic History Review, 2004, 57(4), 636-663. 
Table 1: Summary Statistics

\begin{tabular}{|c|c|c|c|c|c|}
\hline & $\mathrm{N}$ & Mean & $\mathrm{p} 25$ & Median & $\mathrm{p} 75$ \\
\hline \multicolumn{6}{|c|}{ Compensation data from the 2004 Pennsylvania Economy League (PEL) survey } \\
\hline \multicolumn{6}{|c|}{ Municipalities compensating solely on a commission basis: Amount paid } \\
\hline In absolute terms & 203 & $\$ 4,556$ & $\$ 1,371$ & $\$ 3,004$ & $\$ 6,172$ \\
\hline As a percentage of real estate taxes collected & 203 & 4.35 & 3.42 & 4.99 & 5.00 \\
\hline \multicolumn{6}{|l|}{ Municipalities compensating solely on a salary basis: Amount paid } \\
\hline In absolute terms & 50 & $\$ 5,894$ & $\$ 2,500$ & $\$ 4,032$ & $\$ 8,500$ \\
\hline As a percentage of real estate taxes collected & 50 & 1.55 & 0.55 & 1.18 & 1.76 \\
\hline \multicolumn{6}{|l|}{ Compensation data from the Pennsylvania Manual } \\
\hline \multicolumn{6}{|c|}{ Annual salary for municipalities compensating on basis of a flat salary } \\
\hline From the 1985 Manual & 115 & $\$ 9,436$ & $\$ 4,500$ & $\$ 7,500$ & $\$ 12,000$ \\
\hline From the 1989 Manual & 116 & $\$ 10,875$ & $\$ 5,000$ & $\$ 8,850$ & $\$ 14,750$ \\
\hline From the 1993 Manual & 141 & $\$ 15,032$ & $\$ 6,000$ & $\$ 10,000$ & $\$ 20,025$ \\
\hline From the 1997 Manual & 127 & $\$ 17,652$ & $\$ 7,500$ & $\$ 11,968$ & $\$ 25,000$ \\
\hline From the 2001 Manual & 125 & $\$ 19,279$ & $\$ 9,400$ & $\$ 15,000$ & $\$ 26,000$ \\
\hline From the 2005 Manual & 137 & $\$ 19,599$ & $\$ 9,506$ & $\$ 13,138$ & $\$ 27,000$ \\
\hline \multicolumn{6}{|c|}{ Compensation for municipalities paying tax collectors on a commission basis } \\
\hline $\begin{array}{l}\text { As a percentage of real estate taxes collected } \\
\text { (Averaged across all years of the Manual) }\end{array}$ & 39 & 2.81 & 2.00 & 3.00 & 3.50 \\
\hline \multicolumn{6}{|l|}{ Election data from the County Boards of Elections } \\
\hline Probability incumbent runs again for office & 731 & 0.743 & 0 & 1 & 1 \\
\hline Probability incumbent wins office if she runs again & 543 & 0.996 & 1 & 1 & 1 \\
\hline Incumbent's vote share & 543 & 96.7 & 99.2 & 99.8 & 100 \\
\hline Incumbent's vote share (when faced with an opponent) & 42 & 66.7 & 61.2 & 65.6 & 74.1 \\
\hline \multicolumn{6}{|l|}{ Percentage of taxes collected } \\
\hline Sample matched with the PEL survey & 299 & 100.5 & 98.6 & 99.9 & 101.4 \\
\hline Sample matched with data from Pennsylvania Manual & 790 & 99.4 & 97.8 & 99.2 & 100.6 \\
\hline Sample matched with the election data & 716 & 99.6 & 98.3 & 99.3 & 100.7 \\
\hline
\end{tabular}

Notes: Data on compensation of municipal tax collectors from the Pennsylvania Economy League (PEL) is for the year 2004 and pertains to nine counties in Central and Eastern Pennsylvania (Berks, Blair, Dauphin, Lackawanna, Lehigh, Luzerne, Lycoming, Northampton, and York). These data were graciously shared by Gerald Cross of the PEL. Data on compensation from the Pennsylvania Manual is drawn from six issues of the Pennsylvania Manual: Volumes 107, 109, 111, 113, 115, and 117 and they provide tax collector compensation for the years 1985, 1989, 1993, 1997, 2001, and 2005 respectively. Election data are for the period between 2003 and 2009 for sixteen counties (Berks, Butler, Centre, Fulton, Lancaster, Lehigh, Luzerne, Mercer, Monroe, Montgomery, Northampton, Pike, Schuylkill, Venango, Washington, and Westmoreland) and were gathered from websites of the respective County Boards of Elections. Data on percentage of predicted real estate taxes actually collected are based on author's calculations using the municipal financial statistics compiled by the Department of Community and Economic Development of Pennsylvania. The predicted real estate taxes for each municipality are calculated as the product of their assessed value of real estate and the municipal millage rate. Percentage of taxes collected is the ratio of real estate taxes actually collected to the level of real estate taxes predicted based on assessed value and millage rates multiplied by 100 . 
Table 2: Effect of higher compensation of tax collectors on percent real estate taxes collected (using the PEL survey)

Dependent variable: Percentage municipal real estate taxes collected (average for years between 2005 and 2008)

\begin{tabular}{|c|c|c|c|c|}
\hline \multicolumn{5}{|c|}{ Panel A: For municipalities compensating on a commission basis } \\
\hline Compensation & $0.180^{*}$ & $0.172^{*}$ & $0.271 * * *$ & $0.228 * *$ \\
\hline (as percent of taxes collected) & $(1.94)$ & $(1.81)$ & $(2.69)$ & $(2.06)$ \\
\hline \multirow[t]{2}{*}{ Log population } & 0.203 & 0.202 & 0.110 & 0.0983 \\
\hline & $(1.06)$ & (1.04) & $(0.50)$ & $(0.45)$ \\
\hline \multirow[t]{2}{*}{ Millage rate } & & -0.00806 & & -0.0372 \\
\hline & & $(-0.34)$ & & $(-1.14)$ \\
\hline \multirow[t]{2}{*}{ Log of market value of real estate per capita } & & 0.0184 & & -0.0273 \\
\hline & & $(0.05)$ & & $(-0.07)$ \\
\hline \multirow[t]{2}{*}{ Constant } & $97.77 * * *$ & $97.66 * * *$ & $98.09 * * *$ & $98.88 * * *$ \\
\hline & $(58.87)$ & $(21.84)$ & $(54.07)$ & $(19.35)$ \\
\hline $\mathrm{N}$ & 183 & 183 & 183 & 183 \\
\hline $\mathrm{R}^{2}$ & 0.019 & 0.020 & 0.094 & 0.10 \\
\hline \multicolumn{5}{|c|}{ Panel B: For municipalities compensating on a salary basis } \\
\hline \multirow[t]{2}{*}{ Compensation (Log of salary) } & 0.851 & 0.646 & 0.701 & 0.385 \\
\hline & $(1.42)$ & $(1.16)$ & $(0.84)$ & $(0.48)$ \\
\hline \multirow[t]{2}{*}{ Log population } & -0.822 & -0.926 & -0.566 & -0.517 \\
\hline & $(-1.24)$ & $(-1.41)$ & $(-0.76)$ & $(-0.72)$ \\
\hline \multirow[t]{2}{*}{ Millage rate } & & 0.0457 & & 0.0659 \\
\hline & & $(1.10)$ & & $(1.02)$ \\
\hline \multirow[t]{2}{*}{ Log of market value of real estate per capita } & & $1.968^{*}$ & & 2.359 \\
\hline & & $(1.85)$ & & $(1.65)$ \\
\hline \multirow[t]{2}{*}{ Constant } & $100.2^{* * *}$ & $80.31 * * *$ & $99.23^{* * *}$ & $74.37 * * *$ \\
\hline & $(23.83)$ & $(7.01)$ & $(17.07)$ & $(4.86)$ \\
\hline $\mathrm{N}$ & 49 & 49 & 49 & 49 \\
\hline $\mathrm{R}^{2}$ & 0.048 & 0.12 & 0.15 & 0.23 \\
\hline County Fixed Effects & No & No & Yes & Yes \\
\hline
\end{tabular}

Notes: Data on compensation paid to municipal tax collectors is based on data provided by the Pennsylvania Economy League and pertains to nine counties in Central and Eastern Pennsylvania (Berks, Blair, Dauphin, Lackawanna, Lehigh, Luzerne, Lycoming, Northampton, and York). Data on percentage of predicted real estate taxes actually collected are based on author's calculations using the municipal financial statistics compiled by the Department of Community and Economic Development of Pennsylvania. The predicted real estate taxes for each municipality are calculated as the product of their assessed value of real estate and the municipal millage rate. The dependent variable is the ratio of real estate taxes actually collected to the level of real estate taxes predicted based on assessed value and millage rates multiplied by 100. Data on commissions of municipal tax collectors (in Panel A) and salaries (in Panel B) were collected in 2004 and data on percentage of predicted real estate taxes that were actually collected are the averages for years 2005-2008. To reduce the influence of outliers, only those observations for which percent taxes collected lies within the 5th and 95th percentile of the underlying distribution have been used.

Robust t-statistics in parentheses $* \mathrm{p}<0.10, * * \mathrm{p}<0.05, * * * \mathrm{p}<0.01$. 
Table 3: Effect of higher compensation on percent real estate taxes collected for collectors compensated on basis of a commission (using the Pennsylvania Manual)

\begin{tabular}{|c|c|c|}
\hline & (1) & $(2)$ \\
\hline \multicolumn{3}{|c|}{$\begin{array}{l}\text { Dependent variable: Percentage municipal real estate taxes collected } \\
\text { (averaged over a 4-year period) }\end{array}$} \\
\hline Compensation & $0.759^{*}$ & $0.811^{*}$ \\
\hline (as percent of taxes collected) & $(1.74)$ & $(1.74)$ \\
\hline \multirow{2}{*}{ Log population } & 1.650 & 1.733 \\
\hline & $(0.85)$ & $(0.88)$ \\
\hline \multirow[t]{2}{*}{ Millage rate } & & 0.0403 \\
\hline & & $(0.52)$ \\
\hline \multirow[t]{2}{*}{ Log of market value of real estate per capita } & & 0.221 \\
\hline & & $(0.17)$ \\
\hline \multirow[t]{2}{*}{ Constant } & $81.22 * * *$ & $77.76 * * *$ \\
\hline & $(4.33)$ & $(2.82)$ \\
\hline Fixed Effects & None & None \\
\hline $\mathrm{N}$ & 34 & 34 \\
\hline $\mathrm{R}^{2}$ & 0.29 & 0.30 \\
\hline
\end{tabular}

Notes: Data on commissions of municipal tax collectors are from six issues of the Pennsylvania Manual: Volumes 107, 109, 111, 113, 115, and 117. Data on percentage of predicted real estate taxes actually collected are based on author's calculations using the municipal financial statistics compiled by the Department of Community and Economic Development of Pennsylvania. The predicted real estate taxes for each municipality are calculated as the product of their assessed value of real estate and the municipal millage rate. The dependent variable is the ratio of real estate taxes actually collected to the level of real estate taxes predicted based on assessed value and millage rates multiplied by 100 . Data on commissions of municipal tax collectors are for years 1985, 1989, 1993, 1997, 2001, and 2005 and data on percentage of predicted real estate taxes that were actually collected are the averages for the subsequent 4-year periods (e.g. 1986-1989 for the 1985 compensation data, 1990-1993 for the 1989 compensation data, etc.). Period fixed effects (1986-1989, 1990-1993, etc.) are included in all specifications of the table but have not been reported. To reduce the influence of outliers, only those observations for which percent taxes collected lies within the 5th and 95th percentile of the underlying distribution have been used.

Robust t-statistics in parentheses $* \mathrm{p}<0.10, * * \mathrm{p}<0.05, * * * \mathrm{p}<0.01$. 


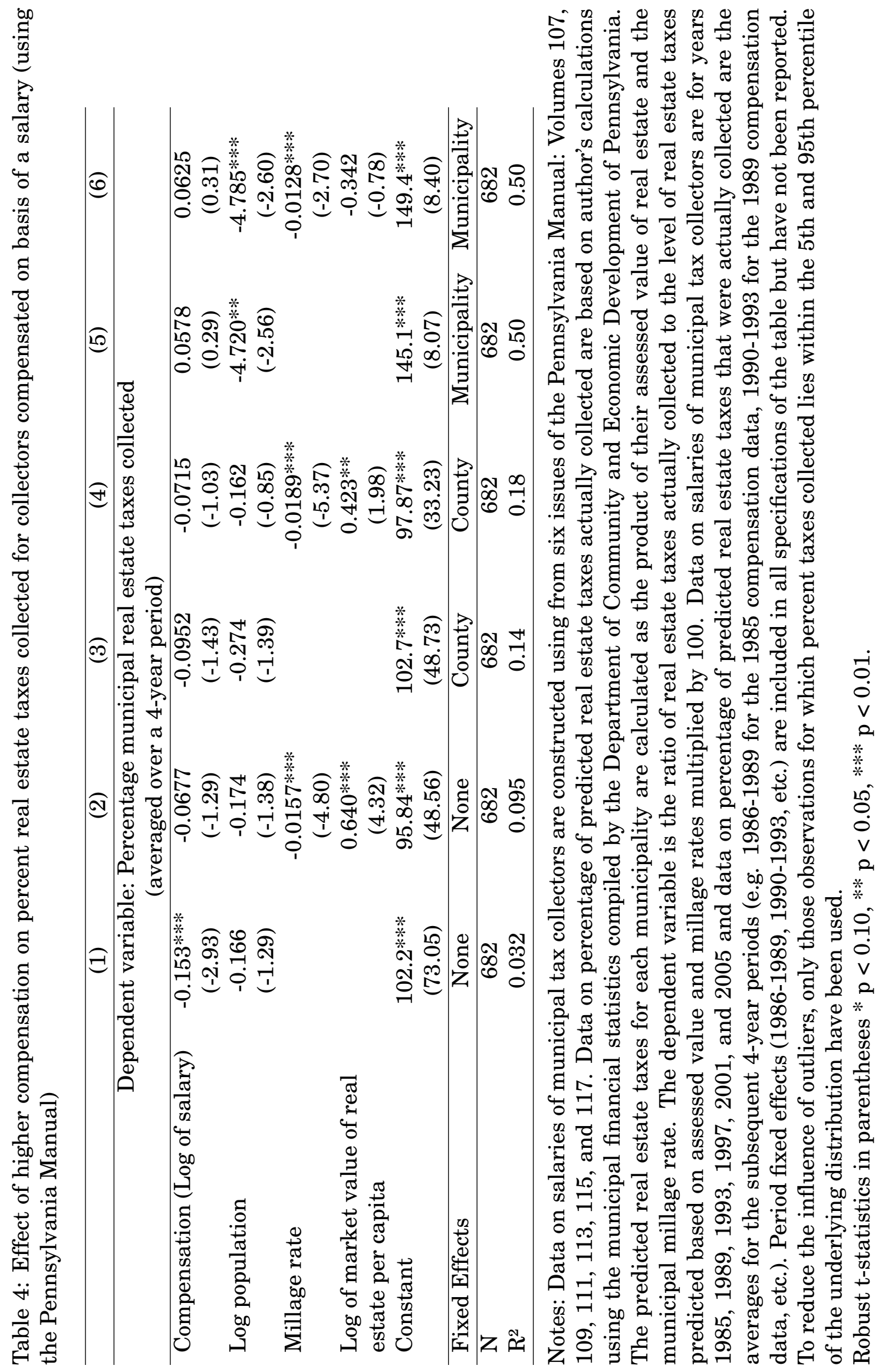




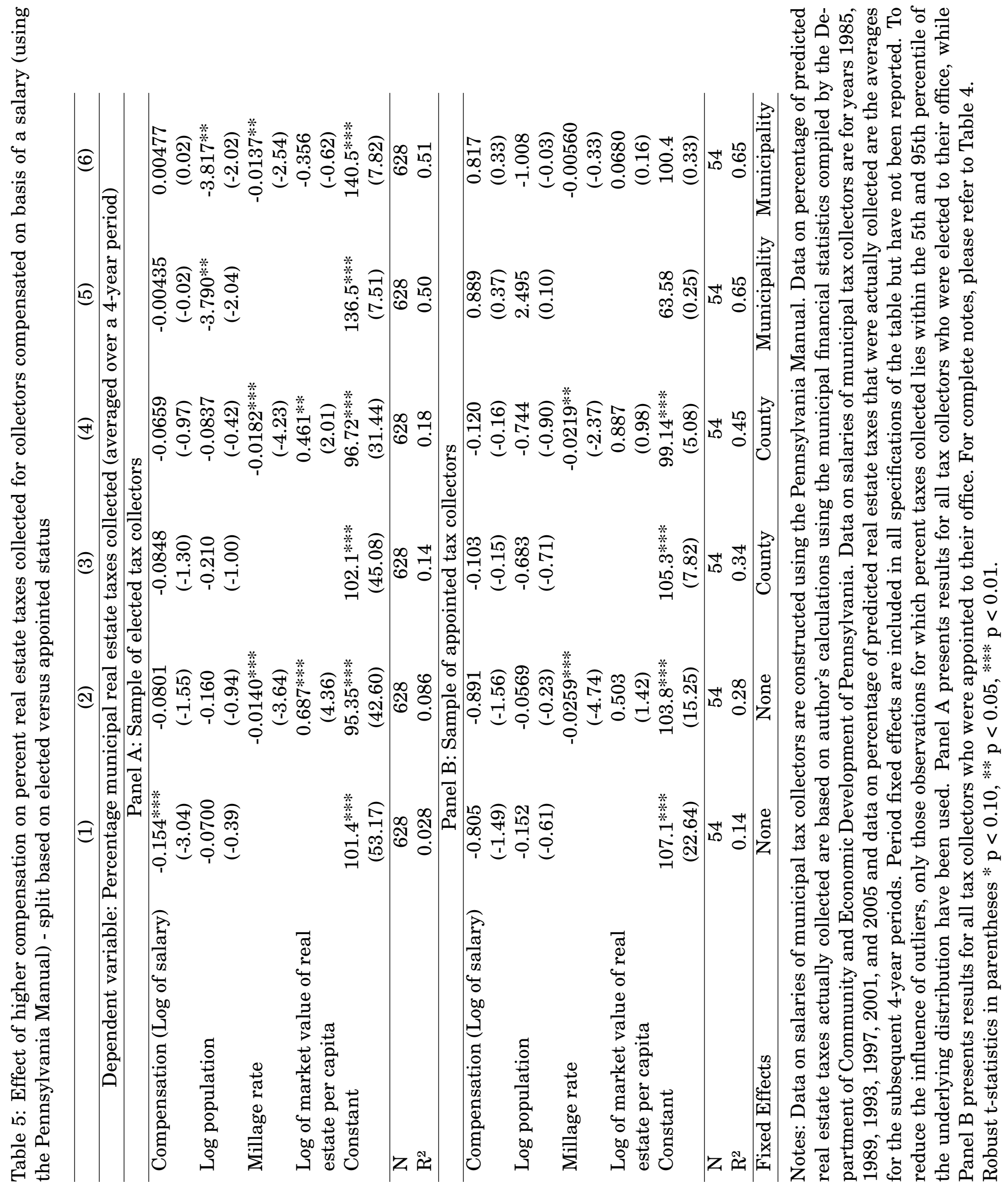




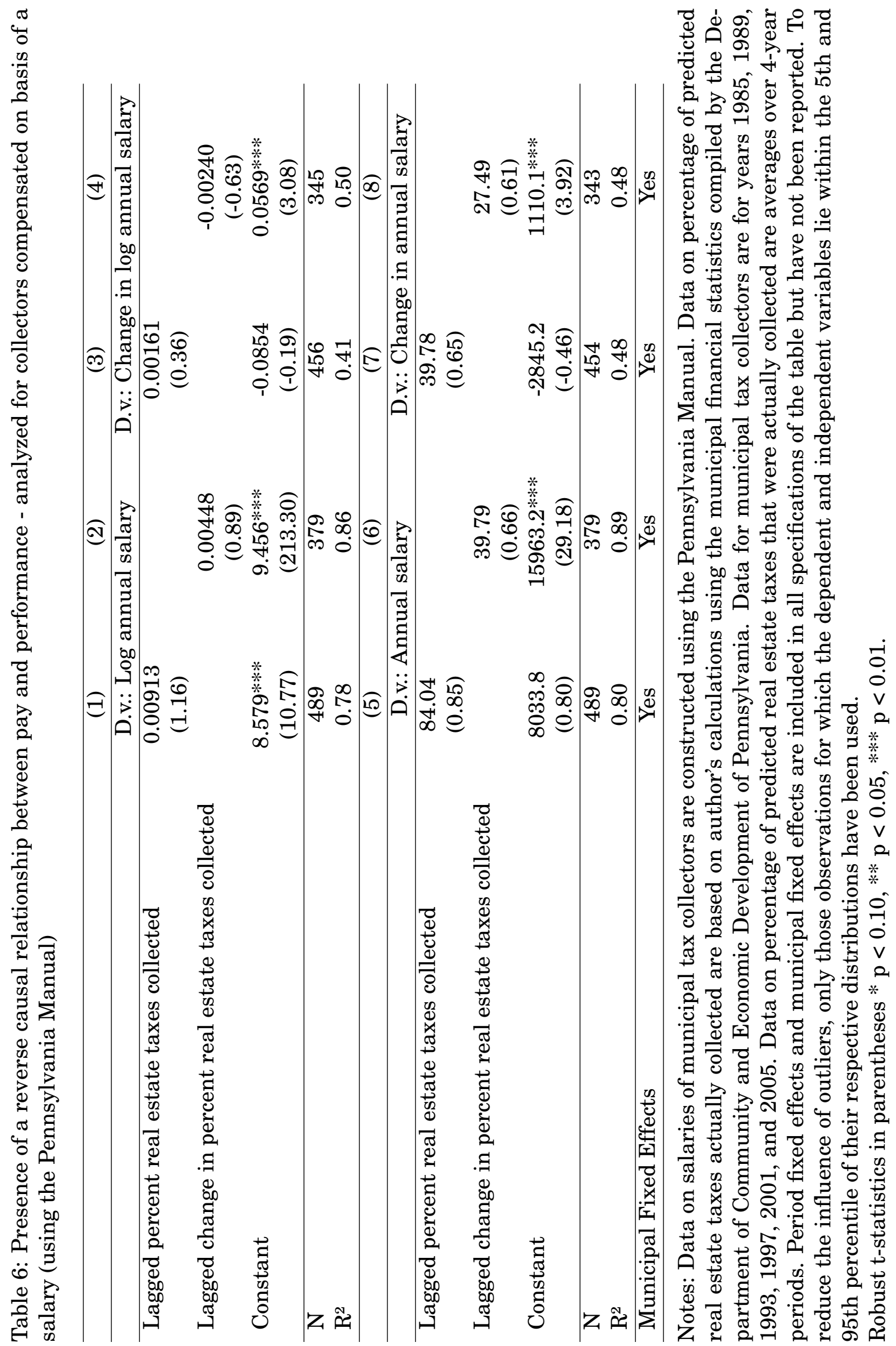




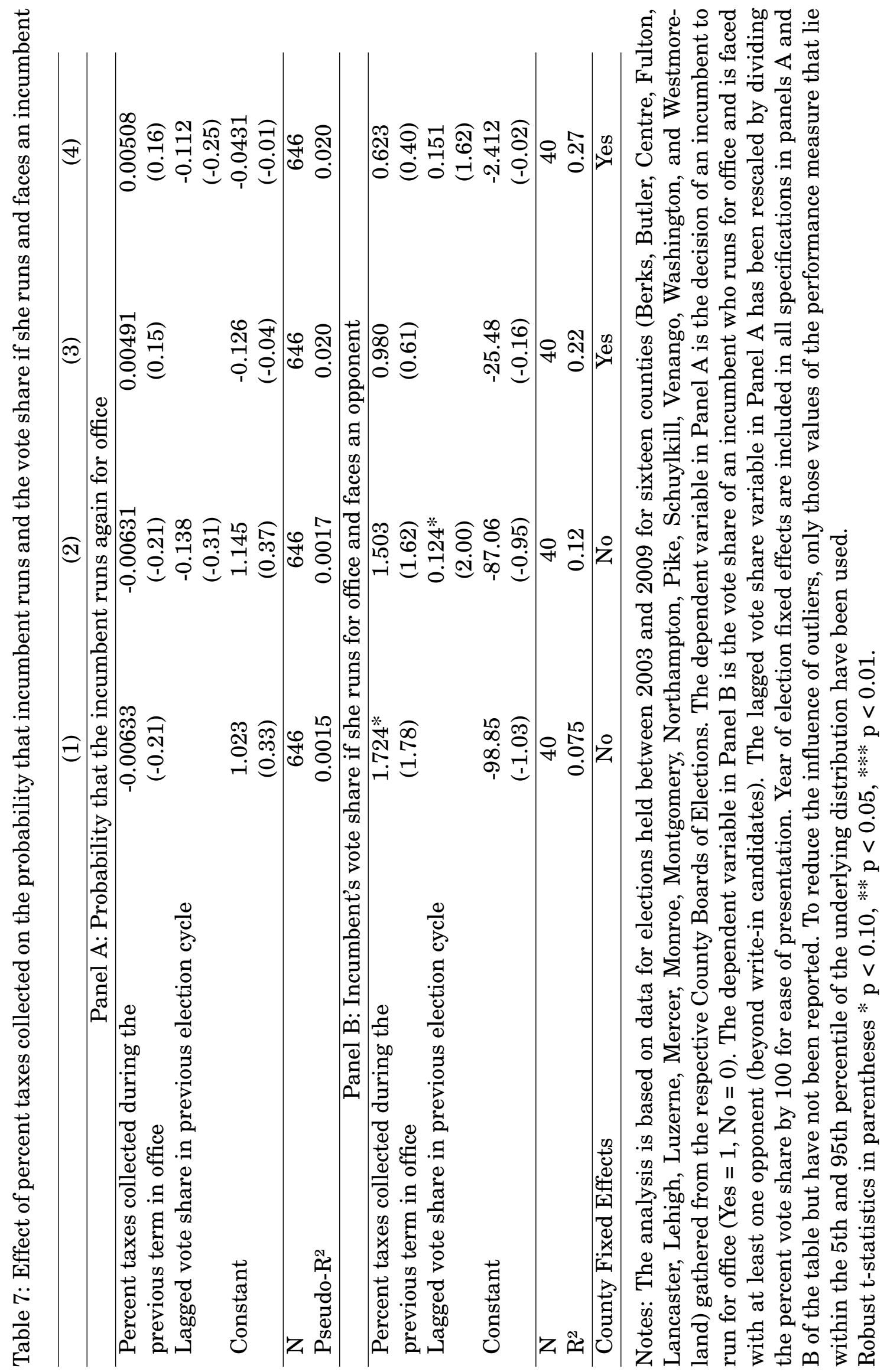




\section{Appendix}

\section{A Proof of result that optimal effort exerted increases when compensation goes up}

Scenario 3: Tax collector compensated on a salary basis and re-election probability depends on the percentage of taxes that are collected:

Our object of interest is $\frac{\partial e^{*}}{\partial S}$.

Examine the FOC:

$$
\frac{\partial c}{\partial e}=\frac{\beta}{(1-\beta * q)} *(S-c(e)) * \frac{\partial q}{\partial e}
$$

Define, $\mathbf{F} \equiv \frac{\partial c}{\partial e}-\frac{\beta}{(1-\beta * q)} *(S-c(e)) * \frac{\partial q}{\partial e}$

By the implicit function theorem: $\frac{\partial e^{*}}{\partial S}=-\frac{\partial F}{\partial S} / \frac{\partial F}{\partial e^{*}}$

$\frac{\partial F}{\partial S}=-\frac{\beta}{(1-\beta * q)} * \frac{\partial q}{\partial e}$

$\frac{\partial F}{\partial e}=\frac{\partial^{2} c}{\partial e^{2}}-\frac{\beta}{(1-\beta * q)} *(S-c(e)) * \frac{\partial^{2} q}{\partial e^{2}}-\frac{\beta}{(1-\beta * q)} *\left(-\frac{\partial c}{\partial e}\right) * \frac{\partial q}{\partial e}-(S-c(e)) * \frac{\partial q}{\partial e} * \frac{\beta^{2}}{(1-\beta * q)^{2}}$.

Or, $\frac{\partial F}{\partial e}=\frac{\partial^{2} c}{\partial e^{2}}-\frac{\beta}{(1-\beta * q)} *(S-c(e)) * \frac{\partial^{2} q}{\partial e^{2}}+\frac{\beta}{(1-\beta * q)} * \frac{\partial c}{\partial e} * \frac{\partial q}{\partial e}-(S-c(e)) * \frac{\partial q}{\partial e} * \frac{\beta^{2}}{(1-\beta * q)^{2}}$. This needs to be evaluated at $e=e^{*}$.

Consider the last two terms of this expression:

$\frac{\beta}{(1-\beta * q)} * \frac{\partial c}{\partial e} * \frac{\partial q}{\partial e}-(S-c(e)) * \frac{\partial q}{\partial e} * \frac{\beta^{2}}{(1-\beta * q)^{2}}$

Partial out $\frac{\beta}{(1-\beta * q)} * \frac{\partial q}{\partial e}$ from each of the individual terms. What we are left with is:

$\frac{\partial c}{\partial e}-(S-c(e)) * \frac{\beta}{(1-\beta * q)}$

Now, because of the FOC, we can say that this is equal to zero when evaluated at $e=e^{*}$.

Hence, $\frac{\partial F}{\partial e}=\frac{\partial^{2} c}{\partial e^{2}}-\frac{\beta}{(1-\beta * q)} *(S-c(e)) * \frac{\partial^{2} q}{\partial e^{2}}$ and therefore, $\frac{\partial e^{*}}{\partial S}=-\frac{\partial F}{\partial S} / \frac{\partial F}{\partial e^{*}}$ translates to

$\frac{\partial e^{*}}{\partial S}=\frac{\beta}{(1-\beta * q)} * \frac{\partial q}{\partial e} /\left[\frac{\partial^{2} c}{\partial e^{2}}-\frac{\beta}{(1-\beta * q)} *(S-c(e)) * \frac{\partial^{2} q}{\partial e^{2}}\right]$

Because, $q$, the re-election probability is a concave function of effort, e, $\frac{\partial q}{\partial e}>0$ and $\frac{\partial^{2} q}{\partial e^{2}}<0$. As a result, both the numerator and denominator of the above expression are positive and I conclude that $\frac{\partial e^{*}}{\partial S}>0$.

Scenario 4: Tax collector compensated on a commission basis and re-election probability depends on the percentage of taxes that are collected:

Here our object of interest is $\frac{\partial e^{*}}{\partial p}$.

Examine the FOC: 


$$
\frac{\partial c}{\partial e}=p * \frac{\partial T}{\partial e}+\frac{\beta}{(1-\beta * q)} *(p * T-c(e)) * \frac{\partial q}{\partial e}
$$

Define, $\mathbf{G} \equiv \frac{\partial c}{\partial e}-p * \frac{\partial T}{\partial e}-\frac{\beta}{(1-\beta * q)} *(p * T-c(e)) * \frac{\partial q}{\partial e}$

By the implicit function theorem: $\frac{\partial e^{*}}{\partial p}=-\frac{\partial G}{\partial p} / \frac{\partial G}{\partial e^{*}}$

$\frac{\partial G}{\partial p}=-\frac{\partial T}{\partial e}-\frac{\beta}{(1-\beta * q)} * T * \frac{\partial q}{\partial e}$

$\frac{\partial G}{\partial e}=\frac{\partial^{2} c}{\partial e^{2}}-p * \frac{\partial^{2} T}{\partial e^{2}}-\frac{\beta}{(1-\beta * q)} *(p * T-c(e)) * \frac{\partial^{2} q}{\partial e^{2}}-\frac{\beta}{(1-\beta * q)} *\left(p * \frac{\partial T}{\partial e}-\frac{\partial c}{\partial e}\right) * \frac{\partial q}{\partial e}-(p * T-c(e)) * \frac{\partial q}{\partial e} * \frac{\beta^{2}}{(1-\beta * q)^{2}}$.

Or, $\frac{\partial G}{\partial e}=\frac{\partial^{2} c}{\partial e^{2}}-p * \frac{\partial^{2} T}{\partial e^{2}}-\frac{\beta}{(1-\beta * q)} *(p * T-c(e)) * \frac{\partial^{2} q}{\partial e^{2}}+\frac{\beta}{(1-\beta * q)} * \frac{\partial c}{\partial e} * \frac{\partial q}{\partial e}-\frac{\beta}{(1-\beta * q)} * p * \frac{\partial T}{\partial e} * \frac{\partial q}{\partial e}-$ $(p * T-c(e)) * \frac{\partial q}{\partial e} * \frac{\beta^{2}}{(1-\beta * q)^{2}}$. This needs to be evaluated at $e=e^{*}$.

Consider the last three terms of this expression:

$\frac{\beta}{(1-\beta * q)} * \frac{\partial c}{\partial e} * \frac{\partial q}{\partial e}-\frac{\beta}{(1-\beta * q)} * p * \frac{\partial T}{\partial e} * \frac{\partial q}{\partial e}-(p * T-c(e)) * \frac{\partial q}{\partial e} * \frac{\beta^{2}}{(1-\beta * q)^{2}}$

Partial out $\frac{\beta}{(1-\beta * q)} * \frac{\partial q}{\partial e}$ from each of the individual terms. What we are left with is:

$\frac{\partial c}{\partial e}-p * \frac{\partial T}{\partial e}-(p * T-c(e)) * \frac{\beta}{(1-\beta * q)}$

Now, because of the FOC, when this is evaluated at $\mathrm{e}=\mathrm{e}^{*}$, this is zero.

Hence, $\frac{\partial G}{\partial e}$

$=\frac{\partial^{2} c}{\partial e^{2}}-p * \frac{\partial^{2} T}{\partial e^{2}}-\frac{\beta}{(1-\beta * q)} *(p * T-c(e)) * \frac{\partial^{2} q}{\partial e^{2}}$

Therefore, $\frac{\partial e^{*}}{\partial p}=-\frac{\partial G}{\partial p} / \frac{\partial G}{\partial e^{*}}$ translates to

$\frac{\partial e^{*}}{\partial p}=\left[\frac{\partial T}{\partial e}+\frac{\beta}{(1-\beta * q)} * \frac{\partial q}{\partial e}\right] /\left[\frac{\partial^{2} c}{\partial e^{2}}-p * \frac{\partial^{2} T}{\partial e^{2}}-\frac{\beta}{(1-\beta * q)} *(p * T-c(e)) * \frac{\partial^{2} q}{\partial e^{2}}\right]$

Because, $q$, the re-election probability is a concave function of effort, e, $\frac{\partial q}{\partial e}>0$ and $\frac{\partial^{2} q}{\partial e^{2}}<0$. Likewise, it makes sense for us to assume that $T$, the taxes that are actually collected are an increasing concave function of $e$ and hence $\frac{\partial T}{\partial e}>0$ and $\frac{\partial^{2} T}{\partial e^{2}}<0$. As a result, both the numerator and denominator of the above expression are positive and I conclude that $\frac{\partial e^{*}}{\partial p}>0$. Now if we were in scenario 2 where re-election probability does not respond to effort exerted, we would have $\frac{\partial e^{*}}{\partial p}=\frac{\partial T}{\partial e} /\left[\frac{\partial^{2} c}{\partial e^{2}}-p * \frac{\partial^{2} T}{\partial e^{2}}\right]$. Because taxes collected, $T$, are a concave function of $e$, while $c$, the cost of effort, is a convex function of $e, \frac{\partial e^{*}}{\partial p}>0$.

\section{B Details of the survey conducted by the Pennsylvania Econ- omy League (PEL)}

The Pennsylvania Economy League (PEL) is a regionally based, nonprofit, nonpartisan public policy organization that provides technical assistance to local governments in Pennsylvania ${ }^{27}$ Around October 2004, the Pennsylvania Economy League (PEL) conducted a survey

\footnotetext{
${ }^{27} \mathrm{http} / / /$ finance.pasenategop.com/files/2015/06/cross.pdf
} 
of tax collector compensation in twelve central and eastern Pennsylvania counties: Berks, Blair, Cambria, Cumberland, Dauphin, Lackawanna, Lancaster, Lehigh, Luzerne, Lycoming, Northampton, and York for the purposes of informing ongoing discussions regarding the reasonableness of the compensation of municipal tax collectors. The data that were provided by Mr. Gerald Cross, Executive Director of the PEL's Central PA Division correspond to nine of those twelve counties: Berks, Blair, Dauphin, Lackawanna, Lehigh, Luzerne, Lycoming, Northampton, and York. The details that are provided below were taken directly from the notes accompanying that data and give some context for the data that were collected.

The figures on taxes collected and compensation presented in this study were gathered using a short and simple survey form which was mailed to each borough, township, and school district in the county. Its purpose was to identify the methods and rates of compensation of all elected tax collectors, total current real estate taxes collected in 2003, the compensation paid, and other relevant data. The figures utilized in this study are essentially "as reported" by the respective municipal and school officials on the forms returned to PEL by September 30, 2004, although some modifications may have been made by PEL staff after conversations with municipal or school officials.

In addition to providing direct compensation, taxing jurisdictions generally underwrite many of the costs incurred by tax collectors including postage, printing, and stationery, as well as the premiums on the tax collectors' bonds and the cost of auditing their records, and are also responsible for the employer's share of Social Security and Medicare taxes. These expenses and various fringe benefit and other costs-some of which are subject to the February 15 deadline for change ${ }^{28}$ - are not included in this study as part of the cost of collecting taxes. It should be noted that in some cases tax collectors incur costs for which they are not reimbursed by the taxing bodies. In these cases the total compensation figures cited in this report would be offset by the unreimbursed expenses, and, therefore, the figures would not be fully comparable with those of tax collectors who have all their costs reimbursed. The costs of compensation presented in this report, however, clearly reflect the amounts which were reported by the municipalities and school districts to have been paid to the elected tax collectors for the collection of real estate taxes in 2003. It should be recognized that in some cases the real

\footnotetext{
${ }^{28}$ Elections for tax collectors are held along with elections to other municipal offices on the first Tuesday of November in odd-numbered years. Any changes to tax collector compensation must be made prior to February 15 of the year in which the tax collectors are elected and taxing jurisdictions are not permitted to alter the established rates of compensation during the term of office of the tax collector or treasurer-except under special circumstances in second class townships with a population of less than 3,000 .
} 
estate tax collections and the corresponding compensation reported to PEL may include data on other taxes, fees, or charges, and the data reported to PEL may include some delinquent taxes as well as penalties and interest.

Appendix Table A.7 summarizes the context specific to each county for which data were provided. As was noted earlier in footnote 10, the response rate to the survey was $74 \%$. I examined if non-response was systematically correlated with the millage rate of the municipality and the market value of real estate per capita but did not find any such evidence. As such, any bias induced by non-response seems not to be of first-order importance. 
Table A.1: Effect of higher compensation on percent real estate taxes collected for collectors (using the PEL survey) using annual nature of the data

\begin{tabular}{|c|c|c|c|c|}
\hline & (1) & $(2)$ & $(3)$ & (4) \\
\hline \multicolumn{5}{|c|}{ Dependent variable: Percentage municipal real estate taxes collected } \\
\hline \multicolumn{5}{|c|}{ Panel A: For municipalities compensating on a commission basis } \\
\hline Compensation & 0.114 & $0.151^{* *}$ & $0.209 * * *$ & $0.198 * *$ \\
\hline (as percent of taxes collected) & $(1.59)$ & $(2.06)$ & $(2.75)$ & $(2.43)$ \\
\hline \multirow[t]{2}{*}{ Log population } & 0.0213 & -0.00549 & -0.0925 & -0.0997 \\
\hline & $(0.14)$ & $(-0.04)$ & $(-0.57)$ & $(-0.62)$ \\
\hline \multirow[t]{2}{*}{ Millage rate } & & 0.0213 & & -0.0203 \\
\hline & & $(1.13)$ & & $(-0.82)$ \\
\hline \multirow[t]{2}{*}{ Log of market value of real estate per capita } & & $0.536^{*}$ & & $0.545^{*}$ \\
\hline & & $(1.79)$ & & $(1.77)$ \\
\hline \multirow[t]{2}{*}{ Constant } & $99.72^{* * *}$ & $93.70 * * *$ & $99.44 * * *$ & $93.61 * * *$ \\
\hline & $(75.23)$ & $(25.73)$ & $(72.07)$ & $(24.05)$ \\
\hline $\mathrm{N}$ & 723 & 723 & 723 & 723 \\
\hline $\mathrm{R}^{2}$ & 0.019 & 0.023 & 0.086 & 0.092 \\
\hline \multicolumn{5}{|c|}{ Panel B: For municipalities compensating on a salary basis } \\
\hline \multirow[t]{2}{*}{ Compensation (Log of salary) } & 0.455 & 0.458 & 0.539 & 0.287 \\
\hline & (1.13) & $(1.10)$ & $(1.08)$ & $(0.57)$ \\
\hline \multirow[t]{2}{*}{ Log population } & -0.231 & -0.397 & -0.00981 & -0.00594 \\
\hline & $(-0.54)$ & $(-0.91)$ & $(-0.02)$ & $(-0.01)$ \\
\hline \multirow[t]{2}{*}{ Millage rate } & & $0.0650 * * *$ & & 0.0501 \\
\hline & & $(2.75)$ & & $(1.29)$ \\
\hline \multirow[t]{2}{*}{ Log of market value of real estate per capita } & & $1.700 * *$ & & $1.815^{* *}$ \\
\hline & & $(2.55)$ & & $(2.32)$ \\
\hline \multirow[t]{2}{*}{ Constant } & $97.36^{* * *}$ & $78.98 * * *$ & $94.68 * * *$ & $75.89 * * *$ \\
\hline & $(30.47)$ & $(12.58)$ & $(24.00)$ & $(9.41)$ \\
\hline $\mathrm{N}$ & 186 & 186 & 186 & 186 \\
\hline $\mathrm{R}^{2}$ & 0.053 & 0.10 & 0.16 & 0.19 \\
\hline County Fixed Effects & No & No & Yes & Yes \\
\hline
\end{tabular}

Notes: Data on compensation paid to municipal tax collectors is based on data provided by the Pennsylvania Economy League and pertains to nine counties in Central and Eastern Pennsylvania (Berks, Blair, Dauphin, Lackawanna, Lehigh, Luzerne, Lycoming, Northampton, and York). Data on percentage of predicted real estate taxes actually collected are based on author's calculations using the municipal financial statistics compiled by the Department of Community and Economic Development of Pennsylvania. The predicted real estate taxes for each municipality are calculated as the product of their assessed value of real estate and the municipal millage rate. The dependent variable is the ratio of real estate taxes actually collected to the level of real estate taxes predicted based on assessed value and millage rates multiplied by 100. Data on commissions of municipal tax collectors (in Panel A) and salaries (in Panel B) are for the year 2004 and data on percentage of predicted real estate taxes that were actually collected are for each year in the subsequent 4-year periods. Year fixed effects are included in all specifications. To reduce the influence of outliers, only those observations for which percent taxes collected lies within the 5th and 95th percentile of the underlying distribution have been used.

Robust t-statistics in parentheses $* \mathrm{p}<0.10, * * \mathrm{p}<0.05, * * * \mathrm{p}<0.01$. 
Table A.2: Effect of higher compensation for collectors paid on a commission basis on percent real estate taxes collected (using the Pennsylvania Manual) using annual nature of the data

\begin{tabular}{lcc}
\hline \multicolumn{2}{c}{$(1)$} & $(2)$ \\
\hline \multicolumn{2}{l}{ Dependent variable: Percentage municipal real estate taxes collected } \\
\hline Compensation & $0.580^{* *}$ & $0.536^{*}$ \\
(as percent of taxes collected) & $(2.04)$ & $(1.94)$ \\
Log population & 0.0489 & 0.0432 \\
& $(0.05)$ & $(0.04)$ \\
Millage rate & & -0.0194 \\
& & $(-0.43)$ \\
Log of market value of real estate per capita & & 0.171 \\
& & $(0.21)$ \\
Constant & $101.6^{* * *}$ & $94.34^{* * *}$ \\
& $(11.45)$ & $(6.28)$ \\
\hline $\mathrm{N}$ & 127 & 127 \\
$\mathrm{R}^{2}$ & 0.27 & 0.28 \\
\hline County Fixed Effects & $\mathrm{No}$ & $\mathrm{No}$ \\
\hline
\end{tabular}

Data on commissions of municipal tax collectors are from the Pennsylvania Manual. Data on percentage of predicted real estate taxes actually collected are based on author's calculations using the municipal financial statistics compiled by the Department of Community and Economic Development of Pennsylvania. The predicted real estate taxes for each municipality are calculated as the product of their assessed value of real estate and the municipal millage rate. The dependent variable is the ratio of real estate taxes actually collected to the level of real estate taxes predicted based on assessed value and millage rates multiplied by 100 . Data on commissions of municipal tax collectors are for years 1985, 1989, 1993, 1997, 2001, and 2005 and data on percentage of predicted real estate taxes that were actually collected are for each year in the subsequent 4-year periods (e.g. 1986-1989 for the 1985 compensation data, 1990-1993 for the 1989 compensation data, etc.). Year fixed effects are included in all specifications of the table but have not been reported. To reduce the influence of outliers, only those observations for which percent taxes collected lies within the 5th and 95th percentile of the underlying distribution have been used.

Robust t-statistics in parentheses $* \mathrm{p}<0.10, * * \mathrm{p}<0.05, * * * \mathrm{p}<0.01$. 


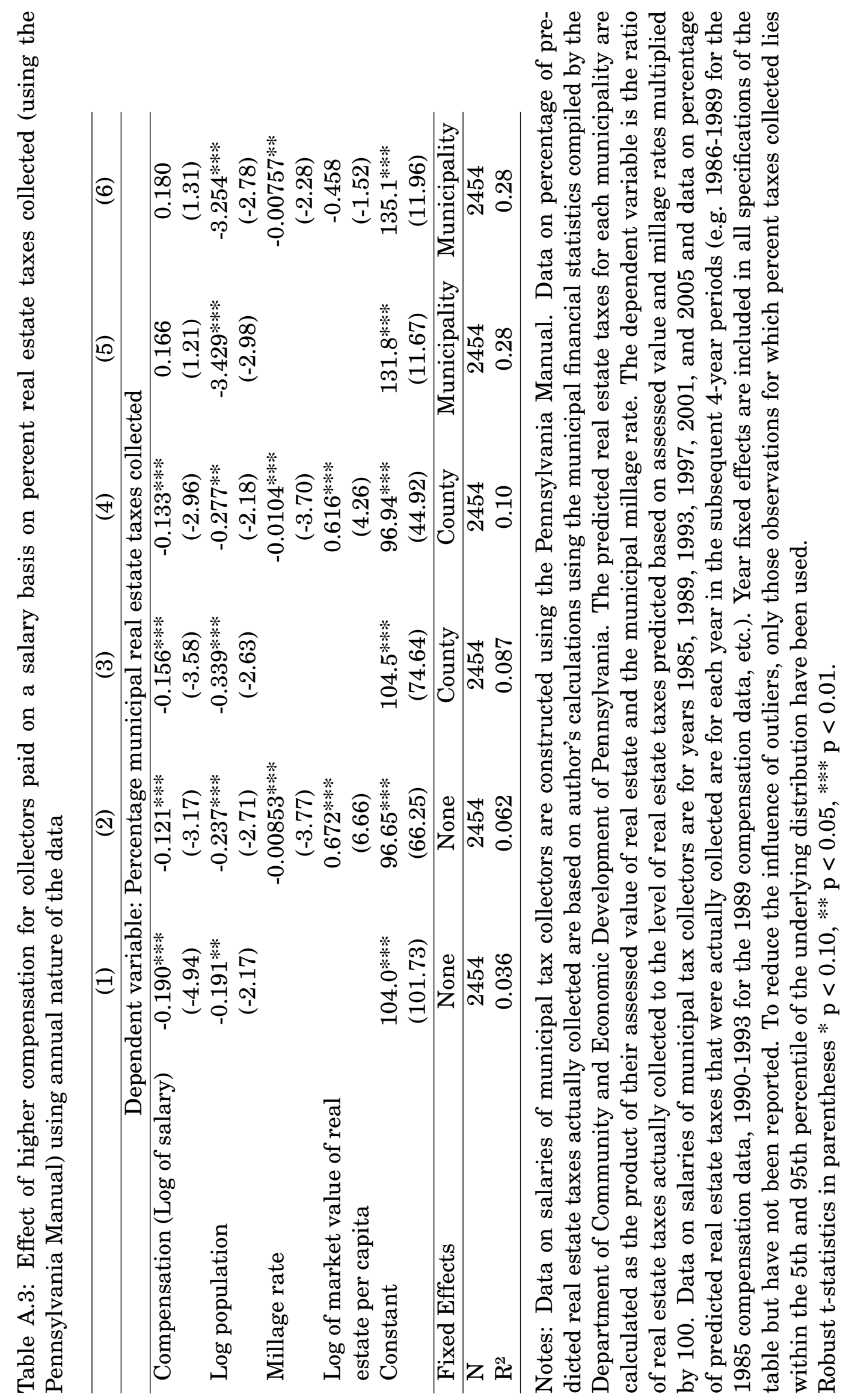




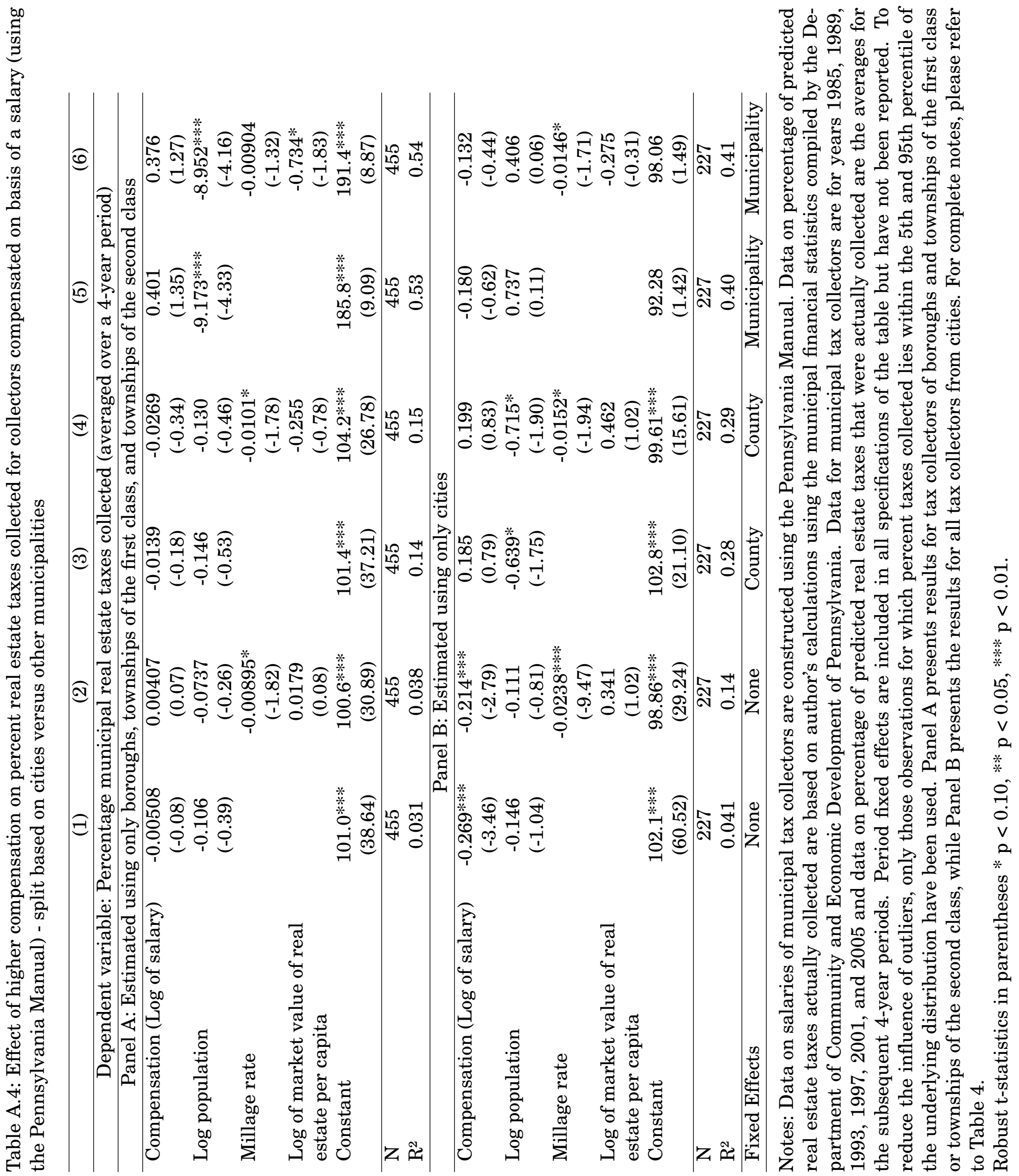




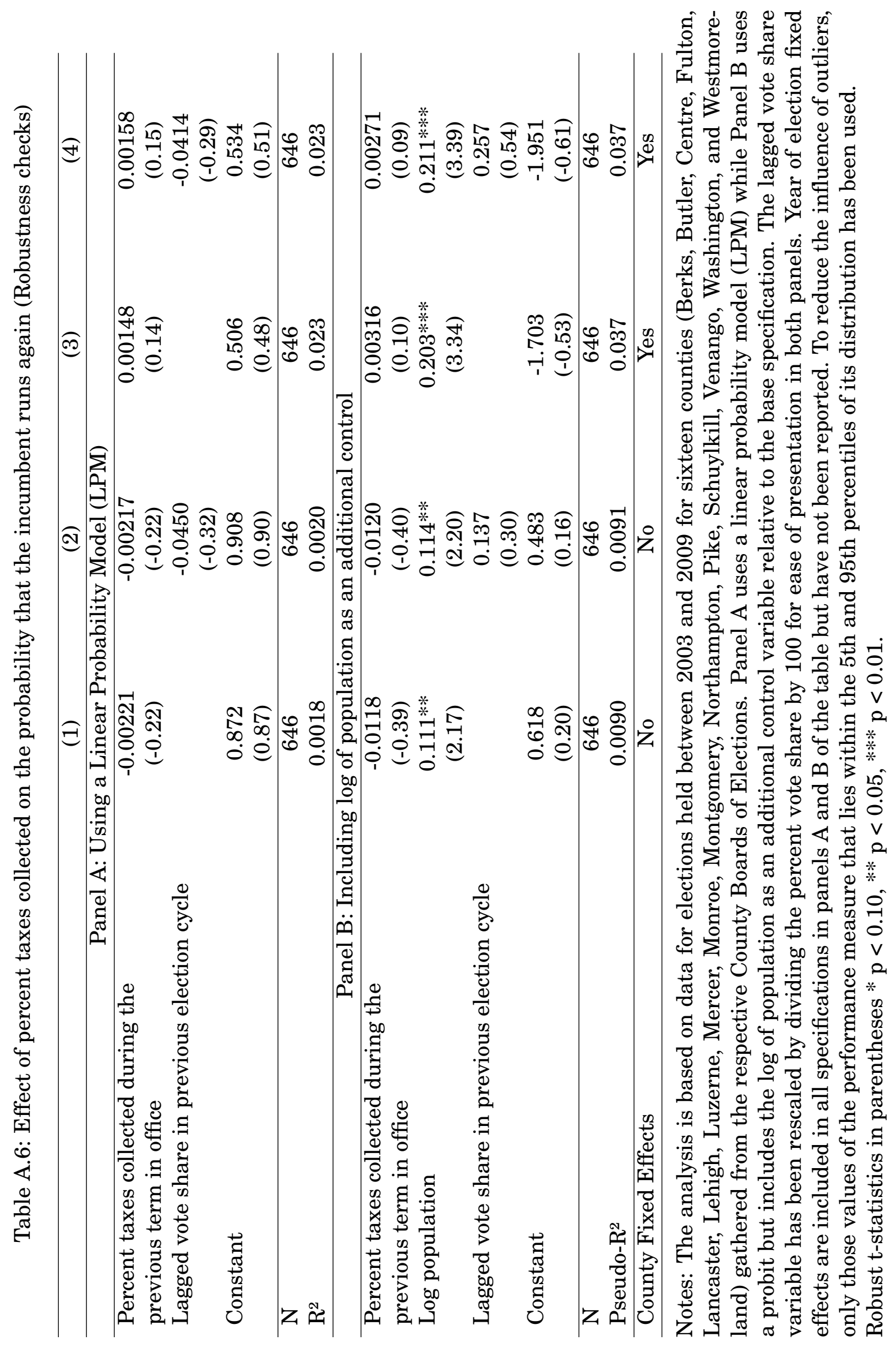




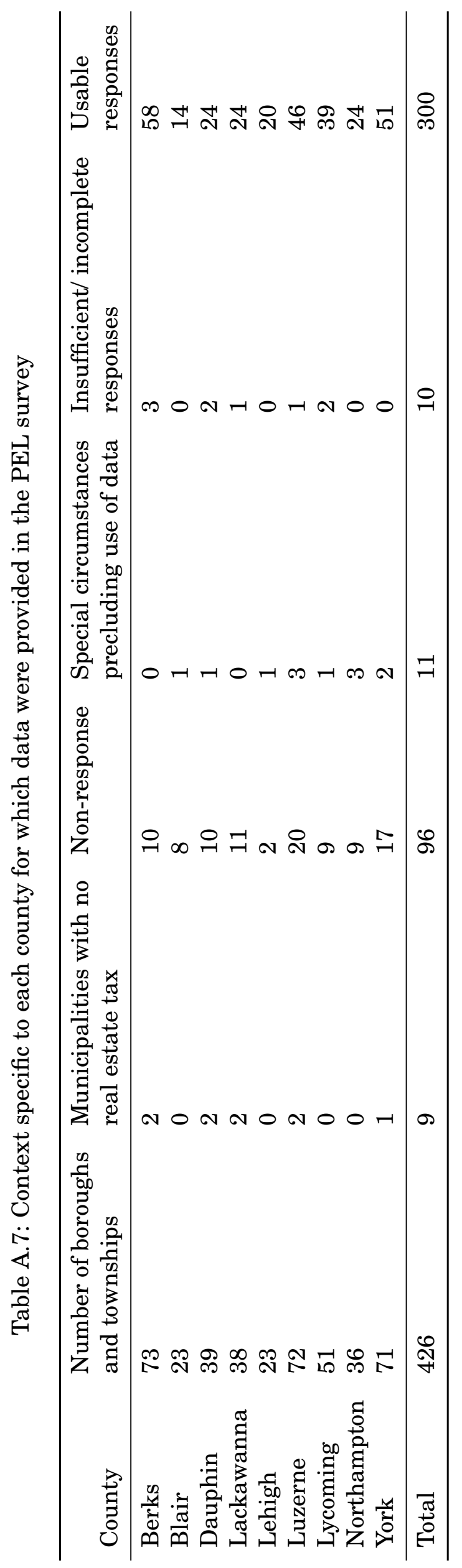

